$10 / 98.92850$

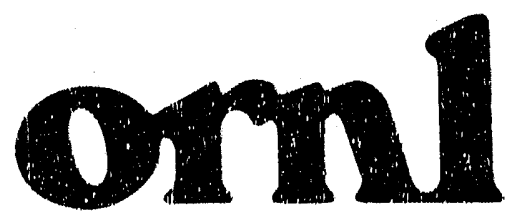

ORNL/TM-12160

OAK RIDGE NATIONAL

LABORATORY

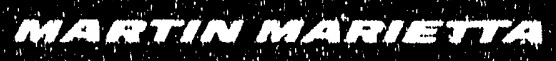

\title{
DNA Radiation Environments Program Spring 1990 2-Meter Box Experiments and Analyses
}

R. T. Santoro

S. Y. Whitaker 
This report has been reproduced directly from the best available copy

Avaluabe to DOE and DOE contractors from the Office of Scientific and Thochi. cal information, P.O Box 62, Oak Ridges. TN 37831; prioes aveilable from (615) 576.8401 , FTS 6.28 .8401

Avalable to the public trom the National Technical Intormation Service, U.S Departiment of Commerce, 5285 Port Foyal Ro, Springhiold, VA 22181.

This report was prepsired as an account of work sponsored by an agency of the United States Government. Noither the United States Government nor any agency thereof, nor any of their employees, makes any warranty, expresa of implied, or assumes any legal tability of responsibility for the accuracy. compheteness, or usefulness of any intormation, apparatus, product, or process dis" closed or repesents that its use would not infringe privately owned rights. Reterence herein to any specitic commercial product, process, or servica by trado name, trademark, manufactuler, or otherwise, does not necbessarity constitute or imply its endorsement, pecommendation, or favoring by the United States Govermment or any agency thereot. The views and opinions of authors expressed herein do mot necessarily state or reflect those of the United Siates Government or any apency thereot 


\title{
DNA RADIATION ENVIRONMENTS PROGRAM SPRING 1990 2-METER BOX EXPERIMENTS AND ANALYSES
}

\author{
R. T. Santoro
}

S. Y. Whitaker

Clark Atlanta University

Atlanta, GA 30314

Date Published: September 1992

Prepared by the

OAK RIDGE NATIONAL LABORATORY

Oak Ridge, Tennessee 37831

managed by

MARTIN MARIETTA ENERGY SYSTEMS, INC

for the

U. S. DEPARTMENT OF ENERGY under contract DE-ACO5-840R21400 


\section{CONTENTS}

\section{Page}

CONTENTS $\ldots \ldots \ldots \ldots \ldots \ldots \ldots \ldots \ldots \ldots \ldots \ldots \ldots$ ii

LIST OF TABLES $\ldots \ldots \ldots \ldots \ldots \ldots \ldots \ldots \ldots \ldots \ldots \ldots$

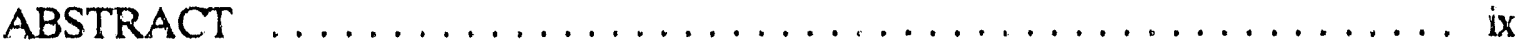

I. INTRODUCTION $\ldots \ldots \ldots \ldots \ldots \ldots \ldots \ldots \ldots \ldots \ldots \ldots$

II. DETAILS OF THE MEASUREMENTS $\ldots \ldots \ldots \ldots \ldots \ldots \ldots$

II.A. APRF MEP.SUREMENTS $\ldots \ldots \ldots \ldots \ldots \ldots \ldots \ldots \ldots$

II.B. HDL MEASUREMENTS $\ldots \ldots \ldots \ldots \ldots \ldots \ldots \ldots \ldots$

II.C. BTI/DREO MEASUREMENTS $\ldots \ldots \ldots \ldots \ldots \ldots \ldots \ldots \ldots 4$

II.D. ETCA MEAUSURMENTS $\ldots \ldots \ldots \ldots \ldots \ldots \ldots \ldots \ldots$

II.E. COMPARISONS OF MEASURED DOSES $\ldots \ldots \ldots \ldots \ldots \ldots 4$

II.F. OBSERVATIONS $\ldots \ldots \ldots \ldots \ldots \ldots \ldots \ldots \ldots \ldots$

III. DETAILS OF THE CALCULATIONS $\ldots \ldots \ldots \ldots \ldots \ldots \ldots$

III.A. CALCULATIONAL INTERCOMPARISON $\ldots \ldots \ldots \ldots \ldots 6$

IV. COMPARISONS OF MEASURED AND CALCULATED DOSES AND REDUCTION FACTORS $\ldots \ldots \ldots \ldots \ldots \ldots \ldots \ldots \ldots \ldots$

IV.A. TLD Gamma-Ray Measurements $\ldots \ldots \ldots \ldots \ldots \ldots \ldots \ldots 8$

IV.A.1. Comparisons with APRF Measurements $\ldots \ldots \ldots \ldots \ldots \ldots$

IV.A.2 Comparisons with HDL Measurements $\ldots \ldots \ldots \ldots \ldots \ldots 9$

IV.A.3 Comparisonss with BTI/DREO Measurements .........9

IV.A.4 Comparisons with ETCA Measurements $\ldots \ldots \ldots \ldots \ldots \ldots 10$ 
IV.B. BD-100R Bubble Detector Neutron Measurements . . . . . . 10

V. CONCLUSIONS AND RECOMMENDATIONS $\ldots \ldots \ldots \ldots \ldots \ldots 11$

VI. REFERENCES $\ldots \ldots \ldots \ldots \ldots \ldots \ldots \ldots \ldots \ldots \ldots \ldots \ldots$

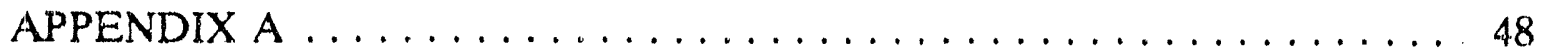




\section{LIST OF TABLES}

Table

Page

1. Details of the 2-Meter Box and Other Experimental Information . . . 12

2. Details of the RT-200 Canadian Humanoid Phantom . . . . . . . . 13

3. APRF Measurements of Gamma-Ray Dose Rate in the Free-Field and as a Function of Position on the RT-200 Humanoid Phantom . . . . . . 14

4. HDL Measurements of Gamma-Ray Dose Rate in the Free-Field and as a Function of Position on the RT-200 Humanoid Phantom . . . . . . 15

5. BTI/DREO Measurement of Neutron Dose Rate in the Free-Field and as a Function of Position on the RT-200 Humanoid Phantom . . . . . . . 16

6. BTI/DREO Measurement of Gamma-Ray Dose Rate in the Free-Field and as a Function of Position on the RT-200 Humanoid Phantom . . . . . . 17

7. ETCA Measurement of Gamma-Ray Dose Rate in the Free-Field and as a Function of Position on the RT-200 Humanoid Phantom . . . . . 18

8. Ratios of the Measured Gamma-Ray Doses Free-Field Measurements/Phantom Facing the Reactor . . . . . . . . . . . . 19

9. Ratios of the Measured Gamma-Ray Doses Phantom in the $2 \mathrm{~m}$ Box/Facing the Reactor . . . . . . . . . . . . . . . . . . . . . . . . . 19

10. Ratios of the Measured Gamma-Ray Doses Free-Field Measurements/Right-Side Facing the Reactor ............. 20

11. Ratios of the Measured Gamma-Ray Doses Phantom in the 2-m Box/RightSide Facing the Reactor . . . . . . . . . . . . . . . . . 20

12. ORNL Calculations of Gamma-Ray Dose Rate in the Free-Field and as a Function of Position on the RT-200 Humanoid Phantom . . . . . . 21

13. ORNL Calculations of Gamma-Ray Dose Rate in the Free-Field and as a Function of Position on the RT-200 Humanoid Phantom . . . . . . 22 
14. SAIC Calculations of Gamma-Ray Dose Rate in the Free-Field and as a Function of Position on the RT-200 Humanoid Phantom . . . . . . 23

15. SAIC Calculations of Gamma-Ray Dose Rate in the Free-Field and as a Function of Position on the RT-200 Humanoid Phantom . . . . . . 24

16. Ratios of the Calculated Gamma-Ray Doses

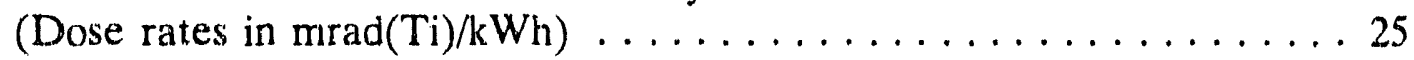

17. Ratios of the Calculated Gamma-Ray Doses

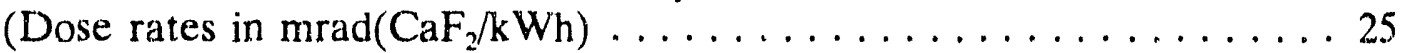

18. ORNL Calculations of Neutron Dose Rate in the Free-Field and as Function of Position on the RT-200 Humanoid Phantom . . . . . . . . 26

19. SAIC Calculations of Neutron Dose Rate in the Free-Field and as a Function of Position on the RT-200 Humanoid Phantom . . . . . . . . . . 27

20. Ratios of the Calculated Neutron Doses

(Dose rates in $\operatorname{mrad}(\mathrm{Ti}) \mathrm{kWh}) \ldots \ldots \ldots \ldots \ldots \ldots \ldots \ldots \ldots \ldots$

21. Measured and Calculated Gamma-Ray Doses and Reduction Factors FreeField/Phantom Facing Reactor Comparisons with APRF TLD Measurements

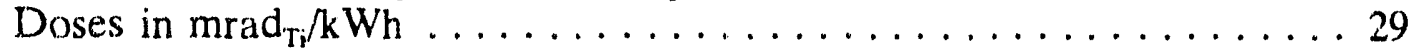

22. Measured and Calculated Gamma-Ray Doses and Reduction Factors In-Box/Phantom Facing Reactor Comparisons with APRF TLD Measurements Doses in $\operatorname{mrad}_{\mathrm{Ti}} / \mathrm{kWh} \ldots \ldots \ldots \ldots \ldots \ldots \ldots \ldots \ldots \ldots \ldots \ldots \ldots$

23. Measured and Calculated Gamma-Ray Doses and Reduction Factors Free-Field/Right-Side Facing Reactor Comparisons with APRF TLD Measurements Doses in $\operatorname{mrad}_{\mathrm{T}} / \mathrm{kWh} \ldots \ldots \ldots \ldots \ldots \ldots \ldots \ldots$

24. Measured and Calculated Gamma-Ray Doses and Reduction Factors In-Box/Right-Side Facing Reactor Comparisons with APRF TLD Measurements Doses in $\operatorname{mrad}_{\mathrm{Tr}} \mathrm{kWh} \ldots \ldots \ldots \ldots \ldots \ldots \ldots \ldots \ldots$

25. Measured and Calculated Gamma-Ray Doses and Reduction Factors Free-Field Phantom Facing Reactor Comparisons with HDL TLD Measurements Doses in $\operatorname{mrad}_{\mathrm{CH}} \mathrm{kWh} \ldots \ldots \ldots \ldots \ldots \ldots \ldots \ldots$ 
26. Measured and Calculated Gamma-Ray Doses and Reduction Factors In-Box/Phantom Facing Reactor Comparisons with HDL. TLD Measurements

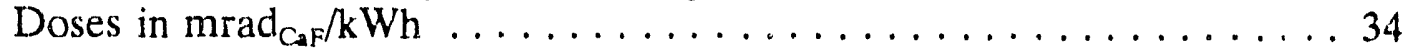

27. Measured and Calculated Gamma-Ray Doses and Reduction Factors Free-Field/Right-Side Facing Reactor Comparisons with HDL TLD Measurements Doses in $\operatorname{mrad}_{\mathrm{CaF}} / \mathrm{kWh} \ldots \ldots \ldots \ldots \ldots \ldots \ldots \ldots$

28. Measured and Calculated Gamma-Ray Doses and Reduction Factors In-Box/Right-Side Facing Reactor Comparisons with HDL TLD Measurements Doses in $\operatorname{mrad}_{\mathrm{CFF}} / \mathrm{kWh} \ldots \ldots \ldots \ldots \ldots \ldots \ldots \ldots$

29. Measured and Calculated Gamma-Ray Doses and Reduction Factors Free-Field/Phantom Facing Reactor Comparisons with BTI/DREO TLD Measurements Doses in $\operatorname{mrad}_{\mathrm{Ti}} / \mathrm{kWh} \ldots \ldots \ldots \ldots \ldots \ldots \ldots . \ldots . \ldots . \ldots$

30. Measured and Calculated Gamma-Ray Doses and Reduction Factors In-Box/Phantom Facing Reactor Comparisons with BTI/DREO TLD

Measurements Doses in $\operatorname{mrad}_{\mathrm{T}} / \mathrm{kWh} \ldots \ldots \ldots \ldots \ldots \ldots \ldots$

31. Measured and Calculated Garnma-Ray Doses and Reduction Factors Free-Field/Right-Side Facing Reactor Comparisons with BTI/DREO TLD Measurements Doses in $\operatorname{mrad}_{\mathrm{Ti}} / \mathrm{kWh} \ldots \ldots \ldots \ldots \ldots \ldots \ldots \ldots$

32. Measured and Calculated Gamma-Ray Doses and Reduction Factors In-Box/Right-Side Facing Reactor Comparisons with BTI/DREO TLD Measurements Doses in $\operatorname{mrad}_{\mathrm{T}} / \mathrm{kWh} \ldots \ldots \ldots \ldots \ldots \ldots \ldots$

33. Measured and Calculated Gamma-Ray Doses and Reduction Factors Free-Field/Phantom Facing Reactor Comparisons with ETCA TLD Measurements Doses in $\operatorname{mrad}_{\mathrm{T} i} / \mathrm{kWh} \ldots \ldots \ldots \ldots \ldots \ldots \ldots \ldots . \ldots 1$

34. Measured and Calculated Neutron Doses and Reduction Factors Free-Field/Phantom Facing Reactor Comparisons with BTI/DREO Bubble Detector Measurements Doses in $\operatorname{mrad}_{\mathrm{Ti}} / \mathrm{kWh} \ldots \ldots \ldots \ldots \ldots .42$

35. Measured and Calculated Neutron Doses and Reduction Factors In-Box/Phantom Facing Reactor Comparisons with BTI/DREO TLD Bubble Detector Measuremenis Doses in $\operatorname{mrad}_{\mathrm{Ti}} / \mathrm{kWh} \ldots \ldots \ldots \ldots \ldots 43$ 
36. Measured and Calculated Neutron Doses and Reduction Factors Free-Field/Right-Side Facing Reactor Comparisons with BTI/DREO Bubble Detector Measurements Doses in $\operatorname{mrad}_{\mathrm{Ti}} / \mathrm{kWh} \ldots \ldots \ldots \ldots \ldots \ldots 44$

37. Measured and Calculated Neutron Doses and Reduction Factors In-Box/Right-Side Facing Reactor Comparisons with BTI/DREO Bubble Detector Measurements Doses in $\operatorname{mrad}_{\mathrm{Ti}} / \mathrm{kWh} \ldots \ldots \ldots \ldots \ldots \ldots$ 


\begin{abstract}
This report summarizes the Spring 1990 2-m Box Experiments performed at the Army Pulse Radiation Facility (APRF) at Aberdeen Proving Ground, Maryland. These studies were sponsored by the Defense Nuclear Agency (DNA) under the Radiation Environments Program to obtain measured data for benchmarking the Adjoint Monte Carlo Code System, MASH, Version 1.0. MASH was developed as the Department of Defense and NATO code system for calculating neutron and gamma-ray radiation fields and shielding protection factors for armored vehicles and military structures against nuclear weapon radiation. In the experiments, neutron and gamma-ray dose and reduction factors were measured in the firee. field and as a function of position on an anthropomorphic phantom that was placed outside and inside the steel-walled $2-\mathrm{m}$ box. The data were acquired at a distance of $400-\mathrm{m}$ from the APRF reactor. The measurements were performed by APRF, Bubble Technology Industries, the Defence Research Establishment Ottawa, Etablissment Technique Central de l'Armement, and Harry Diamond Laboratory. Calculations were carried out by the Oak Ridge National Laboratory and Science Applications International Corporation.
\end{abstract}

The purpose of these experiments was to measure the neutron and gamma-ray dose as a function of detector location on the phantom for cases when the phantom was standing in the free-field and inside of the box. Neutron measurements were made using a BD-100R bubble detector and gamma-ray measurements were made using thermoluminescent detectors (TLD). Calculated and measured data were compared in terms of the $\mathrm{C} / \mathrm{M}$ ratio. DNA mandated that $\mathrm{C} / \mathrm{M}$ values of $\pm 20 \%$ define the acceptable limits for the comparison of the dose and reduction factor data and for qualifying the MASH code in replicating integral parameters.

Neutron measurements were made only by Bubble Technology Industries while gammaray measurements were made by all of the teams of experimentalists. The measured gammaray doses exhibited considerable spread and $\mathrm{C} / \mathrm{M}$ ratios often exceeded $20 \%$. The calculated gamma-ray data reported by ORNL and SAIC were consistently in agreement. The measurec' gamma-ray doses as a function of detector location varied significantly but when the average measured and calculated doses and reduction factors were compared, the $\mathrm{C} / \mathrm{M}$ ratio was within $\pm 20 \%$. The neutron doses and reduction factors showed a similar behavior but, on the average, agreement between the measured and calculated data was within the accepted tolerance. In those cases where large discrepancies occurred in the comparisons of reduction factors, the differences were traceable to disagreement in the measured and calculated freefield doses.

Accepting the $\mathrm{C} / \mathrm{M} \leq 20 \%$ criterion and the consequences of this study, it is recommended that MASH Version 1.0 be adopted by the DOD and NATO for calculating neutron and gamma-ray doses and reduction factors for armored vehicles and other shielded structures. 


\section{INTRODUCTION}

As part of the Radiation Environments Program (REP) sponsored by the Defense Nuclear Agency (DNA), a series of "benchmark" experiments were performed at the Army Pulse Radiation Facility (APRF) at Aberdeen Proving Grounds, Maryland. The purpose of these experiments was to measure neutron and gamma-ray differential and integral spectra, kerma, and dose in the free-field and inside a cubical shaped steel-walled box at a distance of 400 meters from the APRF reactor. The experiments were performed for different box configurations, i.e., unlined and lined and with and without a phantom positioned inside the box. The box has been accepted as the "NATO standard test bed" and the 400 meter distance is defined as the "NATO standard reference point". In all of the experiments, measured data are obtained by experimentalists from different organizations that participate in the REP. The measured data are being used to benchmark the Monte Carlo Adjoint Shielding code system MASH $^{(1)}$ that is being validated under this effort. MASH was developed to replace the Vehicle Code System (VCS) ${ }^{(2,3)}$ for estimating radiation effects inside armored vehicles and other shielded configurations of interest to the military.

In previous reports (Refs 4-6), measured and calculated data were compared for the first in the series of experiments that were performed in the Fall of 1989. Spectra and kerma (dose) were measured using different types of detectors in both the free-field and inside the 2-meter box. This report summarizes the second in the series of experiments. Measurements of neutron and gamma-ray dose as a function of position on an RT-200 Canadian Humanoid Phantom ${ }^{(7)}$ (hereafter referred to as the phantom) that was placed in the standing position in the center of the 2-meter box were performed at the APRF for different box-phantom orientations. These measurements were made during the period 7 May 1990 to 18 May 1990, and are referred to as the Spring 1990 experiments. Measured data were obtained by experimentalists from APRF, Harry Diamond Laboratory (HDL), Bubble Technology Industries (BTI) Canada, the Defence Research Establishment Ottawa (DREO), and the Establissement Technique Central de l'Armement (ETCA). Calculations were carried out by analysts from Oak Ridge National Laboratory (ORNL) and Science Applications International Corporation (SAIC). The organizations and scientists that participated in this study are identified in Appendix A.

Details of the Spring 1990 experiments and comparisons among the data acquired by the different teams of experimentalists are presented in Section II. The calculated data obtained by ORNL and SAIC are compared and discussed in Section III. The measured and calculated data are compared in Section IV and conclusions, observations, and recommendations resulting from this study are presented in Section V. 


\section{DETAILS OF THE MEASUREMENTS}

The 2-meter box assembly used in the Spring 1990 study was the same as that used in the Fall 1989 investigation and described in Refs. 4.6 but, for this study, a phantom was placed in the standing position at the center of the box. Measurements and calculations of neutron and gamma-ray dose were made as a function of detector position on the body of the phantom with the phantom located either in the free-field or inside of the box. One face of the box was always perpendicular to the reactor- $400 \mathrm{~m}$-test site axis and the phantom was positioned inside the box either facing the reactor or turned 90-degrees with the right shoulder facing the radiation source. All of the data were collected at the $400-\mathrm{m}$ reference point. Details of the box and other information concerning the experiments are summarized in Table 1. The RT-200 phantom, including its dimensions, material composition, and the locations on the phantom where doses were measured are described in Table 2.

Ground contour and terrain details, including the position of the reactor relative to the 400 meter test site, were the same as those used in the Fall 1989 investigation and reported in Refs. 4-6. Atmospheric conditions (air temperature, barometric pressure, and relative humidity) and soil moisture content were monitored and recorded by the APRF staff during the measurements. The locations where ground moisture data were measured are shown in the inset in Table 1. Meteorological data recorded during the measurements are summarized in Ref. 8. The meteorological data are mean values obtained from observations taken at regular intervals during the course of the measurements. The soil moisture content during all experiments was relatively constant; on the order of $35 \%$ by weight of dry soil. In all cases, the reactor was operated at steady state power levels and for run durations sufficient to assure acceptable statistical accuracy in the measured data.

The APRF staff coordinated the sequence of experiments and reactor operating conditions to assure minimum interference between participating teams of experimentalists and to optimize reactor operating conditions to achieve experimental goals.

Four box-phantom orientations were studied in the sequence of measurements.

A. Free-field measurement. Phantom located at a distance of $10-\mathrm{m}$ to the side of the box in the standing position facing the reactor.

B. Phantom inside the 2-m box in the standing position facing the reactor.

C. Frex-field measurement. Phantom located at a distance of 10-m to the side of the 2-m box in the standing position with the right shoulder facing the reactor.

D. Phantom inside the $2-m$ box in the standing position with the right shoulder facing the reactor.

Measurements were also made of the free-fieid dose and the free-fieid (attenuated) dose in the box. The free-field dose was measured by placing dosimeters at a distance of $5.40-\mathrm{m}$ 
to the side of the $2-\mathrm{m}$ box at a height of $1.15-\mathrm{m}$ above the ground and a distance of $400-\mathrm{m}$ from the reactor. The attenuated dose (hereafter referred to as the FF-Box dose) was measured by placing dosimeters inside the $2-\mathrm{m}$ box at a height above the floor of the box of $0.68 \mathrm{-m}$ and at a distance of $0.70 \mathrm{-m}$ from the axis of symmetry of the box.

\section{II.A. APRF MEASUREMENTS}

The APRF team utilized $\mathrm{CaF}_{2}: \mathrm{Mn}(3.18 \mathrm{~mm} \times 3.18 \mathrm{~mm} \times 0.89 \mathrm{~mm})$ Harshaw thermoluminescent dosimeters (TLD) to measure the gamma-ray free-field dose, FF. Box dose, and the dose as a function of position on the phantom for the four box-phantom configurations described above. Detailed descriptions of the methods to determine the sensitivity of the TLD's for on surface and in cavity locations on the phantom and the procedure for calibrating the dosimeters using a ${ }^{137} \mathrm{Cs}$ gamma-ray source may be found in the reports by Oliver ${ }^{(9)}$ and Kinzi ${ }^{\left({ }^{(n)}\right.}$.

The gamma ray dose rates in the free-field and as a function of position on the phantom for the different box-phantom configurations are summarized in Table 3 . These data were obtained by placing four TLD chips at each location, averaging the integrated TLD readings (in nanocoulombs), correcting for the background, and converting to dose in units of $\operatorname{mrad}($ tissue) $/ \mathrm{kWh}$. The APRF staff estimated the accuracy of the TL.D system to be better than $\pm 10 \%$ for all measurements. No corrections were made for neutron effects or effects due to the energy dependence of the gamma-ray spectrum.

\section{IIB. HIDL MEASUREMENTS}

HDL employed $\mathrm{CaF}_{2}: \mathrm{Mn}$ thermoluminescent dosimeters (Harshaw TLD-400) to measure the dose as a function of position on the phantom as well as the free field and FF Box doses ${ }^{(11)}$. To achieve greater sensitivity, HDL employed TLD's having dimensions of 6.35 $\mathrm{mm} \times 6.35 \mathrm{~mm} \times 1.78 \mathrm{~mm}$, or eight times the volume of the $3.18 \mathrm{~mm} \times 3.18 \mathrm{~mm} \times 0.89 \mathrm{~mm}$ TLD dosimeter used by the AFRF team. For the free field measurements, the TLD's were enclosed in $1 \mathrm{~g} / \mathrm{cm}^{2}$-thick aluminum capsules. For the phantom measurements, the dosimeters were wrapped in four layers of $25 \mu \mathrm{m}$-thick alumirum foil. The TLD's were placeid adjacent to those being used by the APRF team and exposed for the sanic reactor power-run-times as reported in the APRF measurements. HDI did, however, correct the TLD measurements to account for the effects of thermal neutrons.

The results of the HDL gamma-ray dose rate measurements are summarized in Table 4. Note that the units of dose rate are in $\operatorname{mrad}\left(\mathrm{CaF}_{2}\right)$ per $\mathrm{kWh}$. The dose rates given in Table 4 must be multiplied by a factor of 1.149 to convert these data to dose rate in units of mrad( $\mathrm{Ti})$ per $\mathrm{kWh}$ ( $\mathrm{Ti}=$ tissue) for direct comparison with the results reported by APRF, BTI/DREO, and ETCA. 


\section{II.C. BTIDREO MEASUREMENTS}

Bubble Technology Industries (BTI) and DREO collaborated to measure neutron and garmma ray doses in the free field and as a function of position on the phantom. Neutron dose data were acquired using BD-100R bubble detectors developed by the $B T$ staff and the gamma-ray dose was measured using TLD-400 dosimeters provided by DREO. Details of the experimental procedures and related data are found in Ref. 7 . The neutron dose rate as a function of position on the phantom for the different box-phantom configurations obtained with the $\mathrm{BD}-100 \mathrm{R}$ detectors is summarized in Table 5. The garnma-ray dose rate results obtained using 'TLD's are summarized in Tables 6. Only the data reported in Ref. 7 are used in these comparisons.

\section{II.D. ETCA MEASUREMENTS}

ETCA made only one measurement of the dose rate as a function of position on the RT. 200 phantom: i.e., for the configuration with the phantom in the free field, facing the reactor ${ }^{(12)}$. ETCA used Harshaw TLD 700 dosimeters $(6.4 \mathrm{~mm} \times 6.4 \mathrm{~mm})$. The results of the measurements are summarized in Table 7.

\section{I1.E COMPARISONS OF MEASURED DOSES}

The dose rates reported by each experimental team are compared in terms of the ratios of the measured (M) data; i.e., $\left(M_{\text {Tem }} 1 M_{\text {Team } 2}\right)$ ratios for the various free-field and phanton TLD locations. Only the gamma-ray results are compared here. Neutron measurements that were made by the B'TIDREO team are compared with the calculated neutron dose rate results elsewhere in this report.

The ratios of the measured gamma-ray doses, compared in terms of the APRF/HDL, APRF/BTI, APRF/ETCA, and HDL/BTI, are given i? Tables 8 to 11 for the experiment contigurations $A$ through $D$, described above. ETCA reported results only for configuration A. To equate the data on a consistent basis, the dose rates reported by HDL (given in Table 4) have been multiplied by a factor of 1.149 to convert from units of $\operatorname{mrad}\left(\mathrm{CaF}_{2}\right) / \mathrm{kWh}$ to $\operatorname{mrad}(\mathrm{Ti}) / \mathrm{kWh}$. Also reported is the averag and standard deviation (STD) of the ratios of the measured TLD gamma-ray doses on the phantom.

The doses measured in the free-field with the phantom facing the reactor are shown in Table 8. The results obtained by APRF, HDL, and ETCA agree with each other on the average within nominally $\pm 20 \%$ at nearly all of the detector locations. Exceptions occur at the mid-head (MH) location in the APRF/ETCA comparison where ETCA overestimates the dose relative to the APRF measurements. The BTI doses disagree with the data reported by APRF and HDL; with BTI consistently underestimating the doses. 
Table 9 summarizes the in-box, phantom facing the reactor experiment. The doses measured by APRF, HDL, and BTI are in fairly good agreement for most of the locations reported for this measurement, and except for a few locations, the data agree on the average, within $\pm 20 \%$. The APRF and BTI data are in slight disagreement for the free-field measurement and at the mid-gut (MG) and left wrist (LW) detector locations. The HDL and BTI data show the largest disagreement at the left wrist location.

The measured data obtained by the different teams for the free-field case with the right side of the phantom facing the reactor are compared in Table 10. The APRF and HDL dose measurements on and in the phantom are in moderately good agreement. For the case when the phantom was facing the reactor, the average of the doses agreed within $3 \%$ compared to $12 \%$ for this phantom orientation. The results obtained by the BTI team are consistently lower than the doses reported by APRF but are now in better agreement with the results reported by HDL. In the free-field results reported by all of the teams, the spread among the data are larger when the phantom is facing away from the reactor than for the case when it is facing the reactor. This may be due, in part, to the placement of the TLDs which result in the shielding of some of the detectors by others.

Finally, the measured data for the in-box measurements with the phantom's right shoulder facing the reactor are given in Table 11. For this measurement, phantom doses measured by the three teams are on the average in good agreement except at the right wrist location in the HDL/BTI comparison where BTI overestimates the dose relative to the HDL value.

\section{II.F. OBSERVATIONS}

The largest disparities in the data occur among the free-field doses with no obvious correlation with experiment. The in-box free-field data, on the other hand, are in much better agreement with the largest differences being on the order of $7 \%$. What is most apparent is the large spread in the data and the nonuniform determinations of the dose at TLD positions on the phantom. When the phantom TLD dose ratios are averaged (see bottom of tables), however, the overall agreernent among the data is noticeably improved with the exception of the APRF/B'TI and HDL/BTI comparisons in Table 8 and the APRF/BTI comparison in Table 10. For all of the cases, the APRF and HDL doses are in good agreement assuming the conversion of the HDL dose from $\operatorname{mrad}\left(\mathrm{CaF}_{2}\right) / \mathrm{kWh}$ to $\operatorname{mrad}(\mathrm{Ti}) / \mathrm{kWh}$ is legitimate. Correspondingly, the HDL and BTI data are in good agreement except for the free-field measurement given in Table 9.

The procedure for selecting the ratios among the data in Tables 8 - 11 was entirely arbitrary so the measured data must be carefully examined to reveal the large spread that actually exists between some of the measurements. A further discussion of the spread among the measured data is presented in Section V. 


\section{DETAILS OF THE CALCULATIONS}

Analyses of the 2-m Box/Phantom experiments were carried out separately by researchers from the Oak Ridge National Laboratory and Science Applications International Corporation. Both teams used the MASH code to estimate the dose in the free-field and at detector locations on the phantom for the four experimental configurations described in the previous section. The purpose of conducting two separate analyses was to provide a cross-check of the analytic results and to assure a consistent application of the MASH code system in the benchmarking process.

All of the calculations were performed using the MASH code system, Version $1.0^{(1)}$ that is maintained on the Los Alamos National Laboratory (LANL) CRAY computer. At present, this is the only authorized version of the code system. The transport calculations were carried out using the DABL69 (ENDF/B-V) cross-section library ${ }^{(13)}\left(\mathrm{P}_{5}\right)$ that is also maintained on the LANL CRAY computer. The experimental geometry, including the 2-m Box and the RT. 200 Phantom were replicated in detail using the combinatorial geometry options in the MASH code system. The box and phantom geometries are described in detail in Ref. 8. ORNL and SAIC each used slightly different approaches to calculate the doses in the phantom but both approaches were within the existing capability of the MASH code system.

Air-oyer-ground calculations used to estimate the neutron and gamma-ray fluence in the free-field and on a coupling surface surrounding the box took into account the air and soil moisture content at the time of the measurements. The Monte Carlo (MORSE) calculations to determine the doses at the detector positions on the phantom both inside and outside the box generated and tracked a sufficiently large number of primary source particles to assure adequate sampling over all energy groups. Energy dependent relative importance factors were used to increase the frequency of sampling the adjoint source particles from energy groups having the most significant effect on the dose response function. The secondary particle production probability was set to 1.0 for all regions and energy groups and the in-group energy biasing option in MORSE was turned on for all calculations. Region dependent and energy independent splitting and Russian Roulette parameters were used to improve the statistical accuracy of the Monte Carlo calculations. These options produced an escaping particle to source particle ratio of nominally one.

Statistical uncertainties on the integral neutron and gamma-ray doses were consistently less than $3 \%$ for all calculations.

\section{II.A. CALCULATIONAL INTERCOMPARISON}

The TLD gamma-ray doses calculated by ORNL and SAIC as a function of detector location are given in Tables $12-15$. Tables 12 and 14 report the calculated dose rates in units of mrad(Tissue) per $\mathrm{kWh}$ while the data in Tables 13 and 15 summarize the calculated dose rates in units of $\mathrm{mrad}\left(\mathrm{CaF}_{2}\right)$ per $\mathrm{kWh}$. Also given in each table are the averages and standard deviations of the dose rates on the phantom. These are simple averages and no atte mpt was made to justify the doses as a function of TLD location on the phantom. 
Table 16 compares the data in Tables 12 (ORNL) and 14 (SAIC) in terms of the ratio of the dose rates calculated by ORNL to the dose rates calculated by SAIC. The ratios of the calculated dose rates from Tables 13 (ORNL) and 15 (SAIC) are summarized in Table 17. The estimates of the dose rates on the phantom are generally in very good agreement.

Tables 18 and 19 show the calculated neutron dose rates as a function of experiment and detector location on the phantom obtained by ORNL and SAIC, respectively and Table 20 compares these data in terms of the ratios of the ORNL results to the SAIC results.

The neutron and gamma-ray dose rates calculated by each team are in very good agreement and indicate consistent replication of the experimental configuration, reactor source term, and consistent application of the MASH code system and data. 


\section{COMPARISONS OF MEASURED AND CALCULATED DOSES AND REDUCTION FACTORS}

A considerable amount of data were acquired by each team of experimentalists in the investigation of the four box-phantom configurations. To facilitate the comparisons of the measured and calculated doses and reduction factors, the analytic results are compared with the measured results separately as a function of the team of experimentalist and boxphantom configuration. Given in the following tables are the measured and calculated doses and reduction factors and the calculated-to-measured, $\mathrm{C} / \mathrm{M}$, ratios. Also given in the tables are the averages of the measured and calculated doses and reduction factors and $\mathrm{C} / \mathrm{M}$ ratios for the seven detector locations on the phantom.

\section{IV.A. TLD Gamma-Ray Mensurements}

\section{IV.A.1. Comparisons with APRF Measurements}

The measured gamma-ray doses and reduction factors obtained by the APRF team for the four experiments are compared with the calculated data reported by ORNL and SAIC data in Tables $21-24$. The doses are compared in units of $\operatorname{mrad}(\mathrm{Ti}) / \mathrm{kWh}$. For the measurement with the phantom in the free-field facing the reactor, the results shown in Table 21 indicate that the MASH code system favorably replicates the APRF TLD measurements for detector locations on the phantom. However, the calculated data are in poor agreement with the free-field dose and in-box measurements. The same trend is also observed for the reduction factors. The ORNL calculation poorly replicates the free-field doses and reduction factors while results obtained by SAIC are somewhat better, albeit only marginally. The ORNL and SAIC calculations of the doses and reduction factors as a function of position on the phantom are, on the average, in good agreement with the measurements for this case.

The results obtained for the case when the phantom is in the box and facing the reactor are shown in Table 22 . The calculated free-field results are again in marginal agreement with the measurements while the dose estimates for detector locations on the phantom are in good agreement with the measurements. Neither analytic team does a commendatory job in reproducing the reduction factors for this configuration. The reason for the disparity arnong the reduction factors arises mainly from the large difference between the measured and calculated values of the free-field dose.

For the case when the phantom is in the free-field with the right side facing the reactor, the results given in Table 23 show a very similar behavior to those in Table 21 . The free-field data are in poor agreement while the calculated doses for the detector locations on the phantom are in good agreement with the experimental data. The reduction factors obtained by both analytic teams are in good agreement with the measured results for this case.

Table 24 compares the measured and calculated doses and reduction factors for the case when the phantom is in the box with the right side facing the reactor. The agreement between the calculated and measured free-field doses are again poor compared with the 
correlation for the detectors located on the phantom. For these detectors, the calculations and measurements agree within $\pm 20 \%$. The calculations, however, do not reproduce the measured reduction factors very well for this case.

\section{IV.A.2 Comparisons with HDL Measurements}

The comparisons of the calculated TLD gamma-ray doses and reduction factors with the measured data obtained by the HDL team are compared in Tables $25-28$. The doses are compared in units of $\operatorname{mrad}\left(\mathrm{CaF}_{2}\right)$ per $\mathrm{kWh}$. For the case when the phantom is in the freefield facing the reactor (see Table 25) good agreement is achieved by both ORNL and SAIC for the detector locations on the phantom. The ORNL in-box free-field dose is, however, in marginal agreement with the measured data while the SAIC results are in good agreement. ORNL and SAIC both do a good job of replicating the out of box phantom free-field dose. The reduction factors reported by ORNL and SAIC me in marginal to good agreement with the measured reduction factors.

For the case where the phantom is located in the box facing the reactor, the results given in Table 26 show a considerable improvement in the comparisons among the free-field data but the doses as a function of location on the phantom are now poor to marginal. The spread in measured doses on the phantom are smaller than in the previous case. Examination of the results given in Tables 27 and 28, where the right shoulder of the phantom is facing the reactor, show borderline agreement between the analytic and measured results. The free-field data are in good agreement, the in-box free-field data are in marginal to poor agreement, and, in all cases, marginal to poor agreement is achieved by both teams for the TLD detectors on the phantom.

\section{IV.A.3. Comparisons with BTI/DREO Measurements}

The ORNL and SAIC calculated doses and reduction factors are compared with measured data reported by BTI/DREO in Tables 29 - 32. Tables 29 and 30 compare the results for the cases where the phantom is in the free-field and in the box facing the reactor, respectively. For these cases, good agreement with the measured data is reported by both analytic teams for the free-field, in-box free-field, and at most detector locations on the phantom.

The corresponding experiments for the case when the right side of the phantom is facing the reactor are presented in Tables 31 and 32. The measurements and calculations are again in good agreement at almost all detector locations. In all of the comparisons of calculated doses with the BTI measurements, the largest disparity 
consistently occurs at the mid-gut (MG) location in the phantom where both ORNL and SAIC predict a larger value for the dose than reported by the experimentalists.

\section{IV.A.4. Comparisons with ETCA Measurements}

The ETCA team participated in only one measurement; for the free-field, phantom facing the reactor. The comparisons between the measured and calculated data are summarized in Table 33 and in all cases, the doses in the free-field and on the phantom are in poor agreement. The reduction factors, however, are in good agreement.

\section{IV.B. BD-100R Bubble Detector Neutron Measurements}

The calculated neutron doses in units of $\operatorname{mrad}(\mathrm{Ti})$ per $\mathrm{kWh}$ and concomitant reduction factors are compared with the BTI/DREO BD-100R bubble detector measurements in Tables 34 through 37. In all of the experimental configurations, the agreement between the analytic and experimental free-field doses range from marginal to poor. Both analytic teams consistently overestimate the dose. The comparison of the doses on the phantom display a wide range of differences and scatter among the data. For the cases when the phantom is in the free-field, in both orientations the agreement between the calculated and measured doses for the onsurface detectors is generally good. However, for the detector locations in the midhead and mid-gut, and the back belt position when the phantorn is facing the reactor, large differences between the experimental and analytic data occur. For both cases when the phantom is in the box, the correlation between calculations and measurement is improved. Also, the scatter among the data is smaller.

The neutron reduction factor results also exhibit a large spread and the agreement between the calculated and measured data is generally poor.

The average values of the phantom dose given in the tables should be treated cautiously. The averages are strongly influenced by the doses at detector locations inside the phantom where the neutron attenuation is large. 


\section{CONCLUSIONS AND RECOMMENDATIONS}

The authors of this document were tasked by the Defense Nuclear Agency to examine the results reported by the experimentalists and analysts in an un biased approach. No attempt was made iJ filter inconsistent data or otherwise intervene by adjusting or recalculating doses or reduction factors. In attempting to determine the capability of the MASH code system in replicating the Spring 1990 experiment sequence, it was determined that the best course of action was to examine the plethora of measured and calculated data on a case-by-case basis and report the results.

The results summarized in the tables presented here show agreement between the measured and calculated gamma-ray and neutron doses and reduction factors that range from very good to poor depending on the experimental configuration, detector location (free-field and on-phantom), and the experimental or analytic team reporting the results. The gamma-ray doses reported by the different experimental teams exhibit a large spread among the data for both the free-field and in phantom data. The large scatter among the data is manifested in correspondingly large fluctuations $(>25 \%)$ in the reported reduction factors. The calculated gamma-ray doses reported by ORNL and SAIC, on the other hand, are consistently in good agreement for all of the experimental configurations for both the free-field and in phantom detector locations. When the in-phantom doses and reduction factors are averaged, agreement is considerably improved and in all cases fall within the $\pm 20 \%$ tolerance that was defined as the acceptable limit for these comparisons. Only one experimental team reported neutron doses and reduction factor data. The calculations replicate these results, on the average.

One of the difficulties that arose in tabulating and comparing the gamma-ray doses was that several of the experimental teams reported dose data in different units. The procedure adopted here was to use a simple conversion process to obtain consistency in units of dose. No attempt is made to defend this approach but only to compare the measured and calculated data on a consistent basis. It is strongly recommended that in future DNA sponsored experiments where several teams participate, that the experimentalists review response functions, conversion factors, etc. and report the results in a compatible format. At a minimum, this would reduce confusion and at a maximum might isolate extraneous differences among the data.

The principal purpose for developing the MASH code system was to provide the U.S. Army and in particular the U. S. Army Nuclear and Chemical Agency (USANCA) with the capability to calculate reduction factors of armored vehicle shielding materials against neutron and gamma-rays produced in nuclear weapon explosions. The $\mathrm{C} / \mathrm{M}$ results obtained here show that the MASH code replicates integral data within the accepted tolerance and that MASH version 1.0 can be used to estimate neutron and gamma-ray reduction factors for armored vehicles and other shielded configurations. 
Table 1. Details of the 2-Meter Box and Other Experimental Information.

\begin{tabular}{|c|c|c|c|}
\hline 2-Meter Box & & Box Disposition & \\
\hline Shape & Cubic & Reactor to Box & $400 \mathrm{~m}$ \\
\hline Interior Dimensions & $2.0 \mathrm{~m}$ & 400-m Site Elevation & $10.45 \mathrm{~m}$ \\
\hline Wall Thickness & $0.1016 \mathrm{~m}$ & $\begin{array}{l}\text { Reactor Pad } \\
\text { Elevation }\end{array}$ & $13.58 \mathrm{~m}$ \\
\hline Wall Material & Steel & $\begin{array}{l}\text { Reactor Center } \\
\text { Elevation }\end{array}$ & $26.78 \mathrm{~m}$ \\
\hline
\end{tabular}

400 METER MOISTURE MEASUREMENTS

$$
7 \text { MAY } 1990 \quad 1-2 \text { PM }
$$
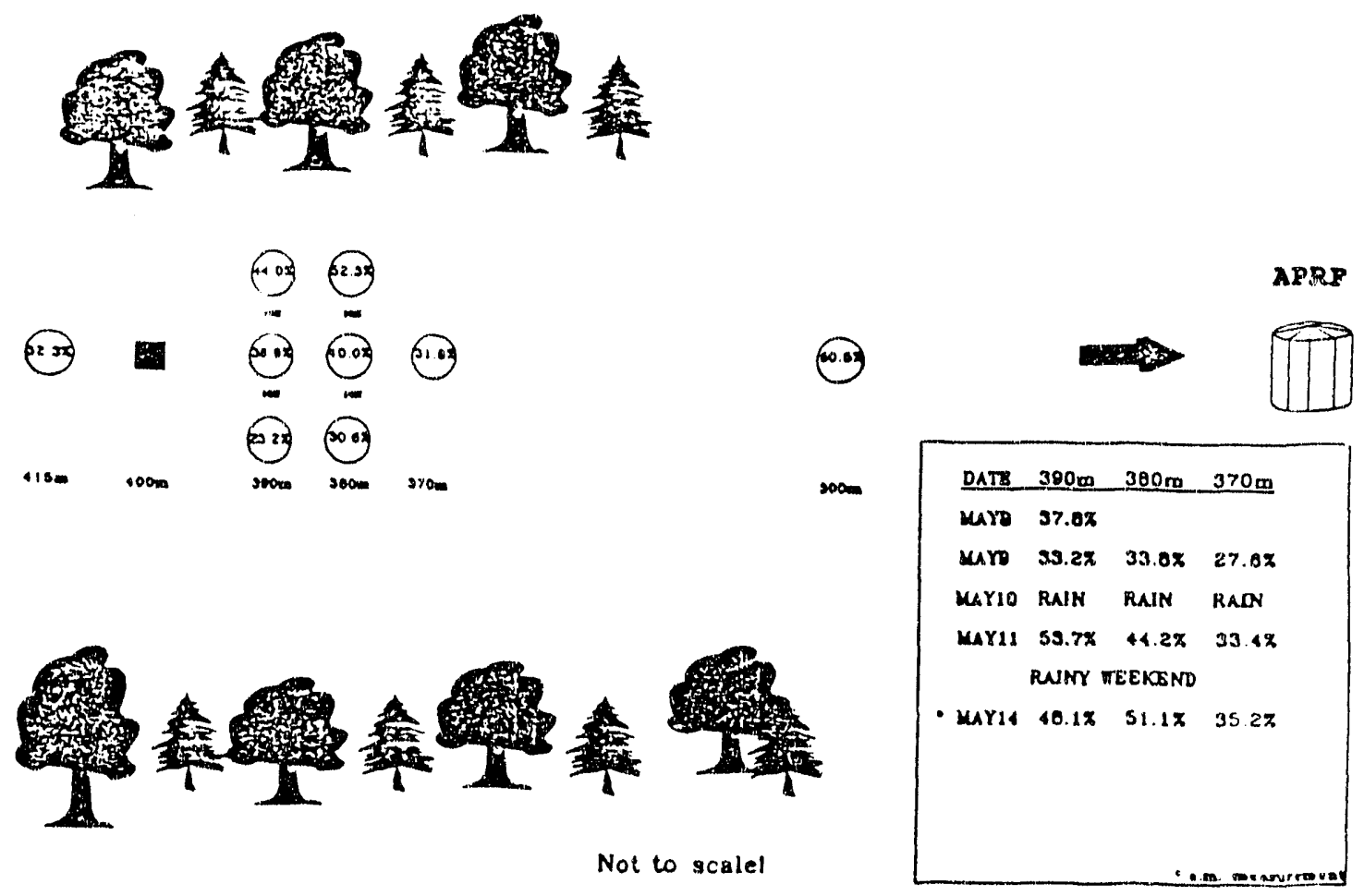
Table 2. Details of the RT-200 Canadian Humanoid Phantom.

\begin{tabular}{|c|c|c|c|c|c|c|}
\hline & \multicolumn{3}{|c|}{ Composition } & \multicolumn{3}{|c|}{$\begin{array}{l}\text { Physical } \\
\text { Parameters }\end{array}$} \\
\hline Element & Lung & Tissue & Bone & & & \\
\hline \multicolumn{7}{|c|}{$\left(\right.$ atoms $\left./ \mathrm{cm}^{3}\right)$} \\
\hline $\mathrm{H}$ & $1.65 \times 10^{-2}$ & $5.88 \times 10^{-2}$ & $6.14 \times 10^{-2}$ & Height & & $175 \mathrm{~cm}$ \\
\hline $\mathrm{C}$ & $1.18 \times 10^{-2}$ & $3.36 \times 10^{-2}$ & $1.79 \times 10^{-2}$ & Chest & (Depth) & 21.4 \\
\hline $\mathrm{N}$ & $1.02 \times 10^{-3}$ & $1.99 \times 10^{-3}$ & $1.84 \times 10^{-3}$ & Chest & (Width) & 33.8 \\
\hline $\mathrm{O}$ & $3.82 \times 10^{-3}$ & $7.72 \times 10^{-3}$ & $2.52 \times 10^{-2}$ & Head & (Depth) & 20.8 \\
\hline $\mathrm{Na}$ & & $2.32 \times 10^{-7}$ & $1.20 \times 10^{-4}$ & Head & (Width) & 14.8 \\
\hline $\mathrm{Mg}$ & & & $3.88 \times 10^{-5}$ & & & \\
\hline $\mathrm{Al}$ & $1.31 \times 10^{-9}$ & $2.29 \times 10^{-9}$ & & Mass & & $74 \mathrm{~kg}$ \\
\hline $\mathrm{Si}$ & & & $6.00 \times 10^{-7}$ & & & \\
\hline$P$ & & & $1.39 \times 10^{-3}$ & & & \\
\hline S & & & $4.55 \times 10^{-5}$ & & & \\
\hline $\mathrm{Cl}$ & $7.13 \times 10^{-8}$ & $2.35 \times 10^{-8}$ & $3.40 \times 10^{-5}$ & & & \\
\hline $\mathrm{K}$ & & & $3.30 \times 10^{-5}$ & & & \\
\hline $\mathrm{Ca}$ & & & $2.14 \times 10^{-3}$ & & & \\
\hline $\mathrm{Fe}$ & & & $1.20 \times 10^{-6}$ & & & \\
\hline \multicolumn{3}{|c|}{$\begin{array}{l}\text { Detector } \\
\text { Legend }\end{array}$} & & & & \\
\hline Free-Field & & Outside & & & & \\
\hline $\mathrm{FF}$ in $\mathrm{Box}$ & & FF Box & & & & \\
\hline Mid Head & & $\mathrm{MH}$ & & & & \\
\hline Mid Gut & & MG & & & & \\
\hline Left Chest & & $\mathrm{LC}$ & & & & \\
\hline Left Wrist & & LW & & & & \\
\hline Rt. Wrist & & RW & & & & \\
\hline Front Belt & & $\mathrm{FB}$ & & & & \\
\hline Back Belt & & $\mathrm{BB}$ & & & & \\
\hline
\end{tabular}


Table 3. APRF Measurements of Gamma-Ray Dose Rate in the Free-Field and as a Function of Position on the RT-200 Humanoid Phantom.

\begin{tabular}{|c|c|c|c|c|c|}
\hline Run Number & & $129 / 130$ & $127 / 128$ & $132,133,134$ & $135 / 136$ \\
\hline \multirow[t]{2}{*}{ Run Length } & & $50 \mathrm{kWh}$ & $50 \mathrm{kWh}$ & $35.2 \mathrm{kWh}$ & $23.8 \mathrm{kWh}$ \\
\hline & & \begin{tabular}{c} 
FF \\
Facing \\
\hdashline $\operatorname{mrad}_{\mathrm{Ti}} / \mathrm{kWh}$ \\
\end{tabular} & $\begin{array}{c}\text { In-Box } \\
\text { Facing } \\
\operatorname{mrad}_{\mathrm{Ti}} / \mathrm{kWh} \\
\end{array}$ & \begin{tabular}{c} 
FF \\
Right Side \\
\hdashline $\operatorname{mrad}_{\mathrm{Ti}} / \mathrm{kWh}$
\end{tabular} & \begin{tabular}{c}
$\begin{array}{c}\text { In-Box } \\
\text { Right Side }\end{array}$ \\
\hdashline $\mathrm{mrad}_{\mathrm{Ti}} / \mathrm{kWh}$
\end{tabular} \\
\hline \multicolumn{6}{|l|}{ Free Field Dose } \\
\hline & & 0.31 & 0.39 & 0.32 & 0.33 \\
\hline \multirow[t]{7}{*}{$\begin{array}{l}\text { Dose in } \\
\text { Phantom }\end{array}$} & $\mathrm{MH}$ & 2.15 & 0.91 & 2.29 & 0.74 \\
\hline & MG & 2.14 & 0.79 & 2.00 & 0.72 \\
\hline & LC & 2.08 & 0.59 & 1.97 & 0.49 \\
\hline & LW & 1.83 & 0.49 & 1.31 & 0.37 \\
\hline & RW & 1.95 & 0.52 & 1.84 & 0.45 \\
\hline & FB & 2.08 & 0.61 & 1.90 & 0.49 \\
\hline & $\mathrm{BB}$ & 1.68 & 0.56 & 1.91 & 0.52 \\
\hline
\end{tabular}


Table 4. HDL Measurements of Gamma-Ray Dose Rate in the Free-Field and as a Function of Position on the RT-200 Humanoid Phantom.

\begin{tabular}{|c|c|c|c|c|c|}
\hline Run Number & & $129 / 130$ & $127 / 128$ & $132 / 133 / 134$ & $135 / 136$ \\
\hline \multirow[t]{2}{*}{ Run Length } & & $50 \mathrm{kWh}$ & $50 \mathrm{kWh}$ & $35.2 \mathrm{kWh}$ & $23.8 \mathrm{kWh}$ \\
\hline & & \begin{tabular}{c} 
FF \\
Facing \\
\hdashline $\operatorname{mrad}_{\mathrm{CaF}} / \mathrm{kWh}$ \\
\end{tabular} & \begin{tabular}{c}
$\begin{array}{c}\text { In-Box } \\
\text { Facing }\end{array}$ \\
\hdashline $\mathrm{mrad}_{\mathrm{CAF}} / \mathrm{kWh}$ \\
\end{tabular} & \begin{tabular}{c} 
FF \\
Right Side \\
\hdashline $\mathrm{mrad}_{\mathrm{C}_{2} \mathrm{~F}} / \mathrm{kWh}$ \\
\end{tabular} & $\begin{array}{c}\text { In-Box } \\
\text { Right Side } \\
\mathrm{d}_{\mathrm{CaF}} / \mathrm{kWh} \\
\end{array}$ \\
\hline \multirow[t]{2}{*}{$\begin{array}{l}\text { Free Field } \\
\text { Dose }\end{array}$} & Outside & 1.33 & 1.32 & 1.31 & 1.31 \\
\hline & FF Box & 0.29 & 0.33 & 0.30 & 0.27 \\
\hline \multirow[t]{7}{*}{$\begin{array}{l}\text { Dose in } \\
\text { Phantom }\end{array}$} & MH & 1.90 & 0.66 & 1.70 & 0.64 \\
\hline & MG & 1.91 & 0.63 & 1.53 & 0.57 \\
\hline & $\mathrm{LC}$ & 1.90 & 0.53 & 1.45 & 0.53 \\
\hline & LW & 1.74 & 0.43 & 1.12 & 0.38 \\
\hline & RW & 1.91 & 0.47 & 1.56 & 0.27 \\
\hline & $\mathrm{FB}$ & 2.10 & 0.49 & 1.47 & 0.41 \\
\hline & $\mathrm{BB}$ & 1.85 & 0.52 & 1.44 & 0.40 \\
\hline
\end{tabular}


Table 5. BTI/DREO Measurement of Neutron Dose Rate in the Free-Field and as a Function of Position on the RT-200 Humanoid Phantom.

\begin{tabular}{|c|c|c|c|c|c|}
\hline Run Number & & $129 / 130$ & $127 / 128$ & $132 / 133 / 134$ & $135 / 135$ \\
\hline \multirow[t]{2}{*}{ Run Length } & & $50 \mathrm{kWh}$ & $50 \mathrm{kWh}$ & $35.2 \mathrm{kWh}$ & $23.8 \mathrm{kWh}$ \\
\hline & & \begin{tabular}{c} 
FF \\
Facing \\
\hdashline mrem/kWh
\end{tabular} & \begin{tabular}{c}
$\begin{array}{c}\text { In-Box } \\
\text { Facing }\end{array}$ \\
\hdashline mrem/kWh
\end{tabular} & \begin{tabular}{c} 
FF \\
Right Side \\
\hdashline mrem/kWh
\end{tabular} & \begin{tabular}{c} 
In-Box \\
Right Side \\
\hdashline mrem/kWH
\end{tabular} \\
\hline \multirow[t]{2}{*}{$\begin{array}{l}\text { Froe Field } \\
\text { Dose }\end{array}$} & Dutside & 46.81 & 48.84 & 47.59 & 40.87 \\
\hline & FF Box & & 27.75 & & 28.40 \\
\hline \multirow[t]{8}{*}{$\begin{array}{l}\text { Dose in } \\
\text { Phantom }\end{array}$} & MH & 10.35 & 3.62 & 9.28 & 4.87 \\
\hline & MG & 7.91 & 2.79 & 5.74 & 2.00 \\
\hline & LC & 42.00 & 26.25 & 27.98 & 19.68 \\
\hline & LW & 37.09 & 23.04 & 21.10 & 20.39 \\
\hline & RW & 47.66 & 26.46 & 41.02 & 28.72 \\
\hline & FB & 38.64 & 21.50 & 27.99 & 19.46 \\
\hline & BB & 17.91 & 13.94 & 23.97 & 18.93 \\
\hline & & $\begin{array}{c}\text { FF } \\
\text { Facing } \\
\operatorname{mrad}(\mathrm{Ti}) / \mathrm{kWh}\end{array}$ & \begin{tabular}{c}
$\begin{array}{c}\text { In-Box } \\
\text { Facing }\end{array}$ \\
\hdashline $\operatorname{mrad}(\mathrm{Ti}) / \mathrm{kWh}$
\end{tabular} & \begin{tabular}{c} 
FF \\
Right Side \\
\hdashline $\operatorname{mrad}(\mathrm{Ti}) / \mathrm{kWh}$
\end{tabular} & $\begin{array}{c}\text { In-Box } \\
\text { Right Side } \\
\text { mrad(Ti)/kWh }\end{array}$ \\
\hline \multirow[t]{2}{*}{$\begin{array}{l}\text { Free Field } \\
\text { Dose }\end{array}$} & Outside & 4.09 & 4.27 & 4.16 & 3.57 \\
\hline & FF Box & & 2.46 & & 2.52 \\
\hline \multirow[t]{7}{*}{$\begin{array}{l}\text { Dose in } \\
\text { Phantom }\end{array}$} & MH & 0.90 & 0.32 & 0.81 & 0.43 \\
\hline & MG & 0.69 & 0.25 & 0.50 & 0.18 \\
\hline & LC & 3.67 & 2.33 & 2.45 & 1.75 \\
\hline & LW & 3.24 & 2.05 & 1.84 & 1.81 \\
\hline & RW & 4.17 & 2.35 & 3.59 & 2.55 \\
\hline & $\mathrm{FB}$ & 3.38 & 1.91 & 2.45 & 1.73 \\
\hline & BB & 1.57 & 1.24 & 2.19 & 1.68 \\
\hline
\end{tabular}


Table 6. BTIDREO Measurement of Gamma-Ray Dose Rate in the Free-Field and as a Function of Position on the RT-200 Humanoid Phantom.

\begin{tabular}{|c|c|c|c|c|c|}
\hline Run Number & & $129 / 130$ & $127 / 128$ & $132 / 133 / 134$ & $135 / 136$ \\
\hline \multirow[t]{2}{*}{ Run length } & & $50 \mathrm{kWh}$ & $50 \mathrm{kWh}$ & $35.2 \mathrm{kWh}$ & $23.8 \mathrm{kWh}$ \\
\hline & & $\begin{array}{c}\text { FF } \\
\text { Facing } \\
\text { mrad }_{\mathrm{Ti}^{\prime}} / \mathrm{kWh}\end{array}$ & $\begin{array}{c}\text { In-Box } \\
\text { Facing } \\
\mathrm{mrad}_{\mathrm{Ti}} / \mathrm{kWh}\end{array}$ & \begin{tabular}{c} 
FF \\
Right Side \\
\hdashline $\operatorname{mrad}_{\mathrm{Ti}} \mathrm{kWh}$
\end{tabular} & \begin{tabular}{c} 
In-Box \\
Right Side \\
\hdashline $\operatorname{mrad}_{\mathrm{Ti}} / \mathrm{kWh}$
\end{tabular} \\
\hline \multirow[t]{2}{*}{$\begin{array}{c}\text { Free Field } \\
\text { Dawe }\end{array}$} & Outside & 1.24 & 1.37 & 1.37 & 1.32 \\
\hline & FF Box & & 0.42 & & 0.33 \\
\hline \multirow[t]{7}{*}{$\begin{array}{l}\text { Dose in } \\
\text { Phantom }\end{array}$} & MH & 1.81 & 0.81 & 1.68 & 0.70 \\
\hline & MG & 1.54 & 0.64 & 1.37 & 0.56 \\
\hline & LC & 1.77 & 0.71 & 1.63 & 0.59 \\
\hline & LW & 1.42 & 0.72 & 1.40 & 0.39 \\
\hline & RW & 1.54 & 0.49 & 1.58 & 0.44 \\
\hline & FB & 1.76 & 0.64 & 1.55 & 0.52 \\
\hline & BB & 1.29 & 0.66 & 1.68 & 0.50 \\
\hline
\end{tabular}


Table 7. ETCA Measurement of Gamma-Ray Dose Rate in the Free-Field and as a Function of Position on the RT-200 Humanoid Phantom.

\begin{tabular}{|c|c|c|}
\hline $\begin{array}{c}\text { Run Number } \\
\text { Length }\end{array}$ & & $\begin{array}{l}129 / 130 \\
50 \mathrm{kWh}\end{array}$ \\
\hline & & \begin{tabular}{c} 
FF \\
Facing \\
\hdashline $\operatorname{mrad}_{\mathrm{Ti}} / \mathrm{kWh}$ \\
\end{tabular} \\
\hline $\begin{array}{l}\text { Free Field } \\
\text { Dase }\end{array}$ & $\begin{array}{l}\text { Outside } \\
\text { FF Box }\end{array}$ & 1.83 \\
\hline \multirow[t]{7}{*}{$\begin{array}{l}\text { Dose in } \\
\text { Phantom }\end{array}$} & $\mathrm{MH}$ & 3.17 \\
\hline & MG & 2.41 \\
\hline & LC & 2.23 \\
\hline & LW & 2.04 \\
\hline & RW & 2.12 \\
\hline & FB & 2.29 \\
\hline & BB & 1.85 \\
\hline
\end{tabular}


Table 8. Ratios of the Measured Gamma-Ray Doses

Free-Field Measurements/Phantom Facing the Reactor

\begin{tabular}{|c|c|c|c|c|c|}
\hline \multirow{2}{*}{$\begin{array}{l}\text { Run Number } \\
\text { Run Length }\end{array}$} & \multirow{2}{*}{$\begin{array}{l}129 / 130 \\
50 \mathrm{kWh}\end{array}$} & \multicolumn{4}{|c|}{ FF Facing } \\
\hline & & APRF/HDL & APRF/BTI & APRF/ETCA & HDL/BTI \\
\hline $\begin{array}{l}\text { Free Field } \\
\text { Dawe }\end{array}$ & $\begin{array}{l}\text { Outside } \\
\text { FF Box }\end{array}$ & $\begin{array}{l}1.11 \\
0.93\end{array}$ & 1.37 & 0.93 & 1.23 \\
\hline \multicolumn{6}{|c|}{ Dowe in the Phantom } \\
\hline & MH & 0.98 & 1.19 & 0.68 & 1.21 \\
\hline & $M G$ & 0.97 & 1.39 & 0.89 & 1.43 \\
\hline & LC & 0.95 & 1.18 & 0.93 & 1.23 \\
\hline & LW & 0.92 & 1.29 & 0.90 & 1.41 \\
\hline & RW & 0.89 & 1.27 & 0.92 & 1.43 \\
\hline & $\mathrm{FB}$ & 0.86 & 1.18 & 0.91 & 1.37 \\
\hline & $\mathrm{BB}$ & 0.79 & 1.30 & 0.91 & 1.65 \\
\hline & Average & 0.91 & 1.26 & 0.88 & 1.39 \\
\hline & STD & 0.07 & 0.08 & 0.09 & 0.15 \\
\hline
\end{tabular}

Table 9. Ratios of the Measured Gamma-Ray Doses

Phantom in the $2 \mathrm{~m} \mathrm{Box/Facing} \mathrm{the} \mathrm{Reactor}$

\begin{tabular}{|c|c|c|c|c|c|}
\hline \multirow{2}{*}{$\begin{array}{l}\text { Run Number } \\
\text { Run Length }\end{array}$} & \multirow{2}{*}{$\begin{array}{l}127 / 128 \\
50 \mathrm{kWh}\end{array}$} & \multicolumn{4}{|c|}{ In Bax Facing } \\
\hline & & APRF/HDL & APRF/BTI & APRF/E'TCA & HDL/BTI \\
\hline $\begin{array}{l}\text { Froe Field } \\
\text { Dowe }\end{array}$ & $\begin{array}{l}\text { Outside } \\
\text { FF Bax }\end{array}$ & $\begin{array}{l}1.11 \\
1.03\end{array}$ & $\begin{array}{l}1.23 \\
0.93\end{array}$ & & $\begin{array}{l}1.11 \\
0.90\end{array}$ \\
\hline \multicolumn{6}{|c|}{ Dose in the Ptantom } \\
\hline & MH & 1.20 & 1.12 & & 0.94 \\
\hline & MG & 1.09 & 1.23 & & 1.13 \\
\hline & LC & 0.97 & 0.83 & & 0.86 \\
\hline & LW & 0.99 & 0.68 & & 0.69 \\
\hline & RW & 0.96 & 1.06 & & 1.10 \\
\hline & FB & 1.08 & 0.95 & & 0.88 \\
\hline & $\mathrm{BB}$ & 0.94 & 0.85 & & 0.90 \\
\hline & Average* & 1.03 & 0.96 & & 0.93 \\
\hline & STD & 0.09 & 0.19 & & 0.15 \\
\hline
\end{tabular}

Average of the Ratwx in the Phantom. 
Table 10. Ratios of the Measured Gamma-Ray Doses Free-Field Measurements/Right-Side Facing the Reactor

\begin{tabular}{|c|c|c|c|c|c|}
\hline \multirow{2}{*}{$\begin{array}{l}\text { Run Number } \\
\text { Run Leagth }\end{array}$} & \multirow{2}{*}{$\begin{array}{l}132 / 133 / 134 \\
35.2 \mathrm{kWh}\end{array}$} & \multicolumn{4}{|c|}{ FF Right Side } \\
\hline & & APRF/HDL & APRF/BTI & APRF/ETCA & HDL/BTT \\
\hline $\begin{array}{l}\text { Froe Fiedd } \\
\text { Dose }\end{array}$ & $\begin{array}{l}\text { Outside } \\
\text { FF Bax }\end{array}$ & $\begin{array}{l}1.14 \\
0.93\end{array}$ & 1.26 & & 1.10 \\
\hline \multicolumn{6}{|c|}{ Done in the Phnatore } \\
\hline & MH & 1.17 & 1.36 & & 1.16 \\
\hline & MG & 1.14 & 1.46 & & 1.28 \\
\hline & LC & 1.18 & 1.21 & & 1.02 \\
\hline & LW & 1.02 & 0.94 & & 0.92 \\
\hline & FW & 1.03 & 1.16 & & 1.13 \\
\hline & $\mathrm{FB}$ & 1.12 & 1.23 & & 1.09 \\
\hline & BB & 1.15 & 1.14 & & 0.99 \\
\hline & Average" & 1.12 & 1.21 & & 1.08 \\
\hline & STD & 0.07 & 0.17 & & 0.12 \\
\hline
\end{tabular}

Average of the Ratios in the phantom

Table 11. Ratios of the Measured Gamma-Ray Doses

Phantom in the 2-m Bar/Right-Side Facing the Reactor

\begin{tabular}{|c|c|c|c|c|c|}
\hline \multirow[t]{2}{*}{$\begin{array}{l}\text { Rus Number } \\
\text { Ruen Leagth }\end{array}$} & \multirow[t]{2}{*}{$\begin{array}{l}135 / 136 \\
23.8 \mathrm{kWh}\end{array}$} & \multicolumn{4}{|c|}{$\begin{array}{c}\text { In Bax } \\
\text { Right Side Facing }\end{array}$} \\
\hline & & APRF/HDL & APRF/BTl & APRF/ETCA & HDL/BTI \\
\hline $\begin{array}{l}\text { Froe Fiedd } \\
\text { Douse }\end{array}$ & $\begin{array}{l}\text { Outside } \\
\text { FF Bax } \\
\end{array}$ & $\begin{array}{l}1.14 \\
1.06 \\
\end{array}$ & $\begin{array}{l}1.29 \\
1.00 \\
\end{array}$ & & $\begin{array}{l}1.14 \\
0.94\end{array}$ \\
\hline \multicolumn{6}{|c|}{ Done in the Phantom } \\
\hline & MH & 1.01 & 1.06 & & 1.05 \\
\hline & MG & 1.10 & 1.29 & & 1.17 \\
\hline & LCC & 0.80 & 0.83 & & 1.03 \\
\hline & LW & 0.85 & 0.95 & & 1.12 \\
\hline & RW & 1.45 & 1.02 & & 0.70 \\
\hline & $\mathrm{FB}$ & 1.04 & 0.94 & & 0.91 \\
\hline & $\mathrm{BB}$ & 1.13 & 1.04 & & 0.92 \\
\hline & Average" & 1.05 & 1.02 & & 0.99 \\
\hline & STD & 0.21 & 0.14 & & 0.16 \\
\hline
\end{tabular}

Average of the Ratios in the Phantom. 
Table 12. ORNL Calculations of Gamma-Ray Dose Rate in the Free-Field and as a Function of Position on the RT-200 Humanoid Phantom.

\begin{tabular}{|c|c|c|c|c|c|}
\hline Run Number & & $129 / 130$ & $127 / 128$ & $132 / 133 / 134$ & $135 / 136$ \\
\hline \multirow[t]{2}{*}{ Run Length } & & $50 \mathrm{kWh}$ & $50 \mathrm{kWh}$ & $35.2 \mathrm{kWh}$ & $23.8 \mathrm{kWh}$ \\
\hline & & $\begin{array}{c}\text { FF } \\
\text { Facing } \\
\operatorname{mrad}_{\mathrm{Ti}} / \mathrm{kWh}\end{array}$ & \begin{tabular}{c}
$\begin{array}{c}\text { In-Box } \\
\text { Facing }\end{array}$ \\
\hdashline $\mathrm{mrad}_{\mathrm{Ti}} / \mathrm{kWh}$ \\
\end{tabular} & \begin{tabular}{c} 
FF \\
Right Side \\
\hdashline $\operatorname{mrad}_{\mathrm{Ti}} / \mathrm{kWh}$ \\
\end{tabular} & \begin{tabular}{c}
$\begin{array}{c}\text { In-Box } \\
\text { Right Side }\end{array}$ \\
\hdashline $\operatorname{mrad}_{\mathrm{Ti}} / \mathrm{kWh}$
\end{tabular} \\
\hline \multirow[t]{2}{*}{$\begin{array}{l}\text { Free Field } \\
\text { Dase }\end{array}$} & Outside & 1.34 & 1.33 & 1.34 & 1.32 \\
\hline & FF Box & 0.38 & 0.38 & 0.38 & 0.35 \\
\hline \multirow[t]{7}{*}{$\begin{array}{l}\text { Dase in } \\
\text { Phantom }\end{array}$} & $\mathrm{MH}$ & 1.93 & 0.93 & 1.98 & 0.81 \\
\hline & MG & 1.92 & 0.85 & 1.73 & 0.73 \\
\hline & LC & 1.84 & 0.66 & 1.58 & 0.55 \\
\hline & L.W & 1.51 & 0.47 & 1.19 & 0.39 \\
\hline & $\mathrm{RW}$ & 1.61 & 0.52 & 1.63 & 0.49 \\
\hline & FB & 1.93 & 0.69 & 1.68 & 0.58 \\
\hline & $\mathrm{BB}$ & 1.48 & 0.63 & 1.72 & 0.58 \\
\hline Average & & 1.75 & 0.68 & 1.64 & 0.59 \\
\hline STD & & 0.20 & 0.17 & 0.24 & 0.14 \\
\hline
\end{tabular}


Table 13. ORNL Calculations of Gamma-Ray Dose Rate in the Free-Field and as a Function of Position on the RT-200 Humanoid Phantorn.

\begin{tabular}{|c|c|c|c|c|c|}
\hline Run Number & & $129 / 130$ & $127 / 128$ & $132 / 133 / 134$ & $135 / 136$ \\
\hline \multirow[t]{2}{*}{ Run Length } & & $50 \mathrm{kWh}$ & $50 \mathrm{kWh}$ & $35.2 \mathrm{kWh}$ & $23.8 \mathrm{kWh}$ \\
\hline & & $\begin{array}{c}\text { FF } \\
\text { Facing } \\
\operatorname{mrad}_{\mathrm{CaF}} / \mathrm{kWh} \\
\end{array}$ & \begin{tabular}{c} 
In-Box \\
Facing \\
\hdashline $\operatorname{mrad}_{\mathrm{CAF}} / \mathrm{kWh}$ \\
\end{tabular} & \begin{tabular}{c} 
FF \\
Right Side \\
\hdashline $\mathrm{mrad}_{\mathrm{CaF}} / \mathrm{kWh}$ \\
\end{tabular} & \begin{tabular}{c} 
In-Box \\
Right Side \\
\hdashline $\operatorname{mrad}_{\mathrm{C} F \mathrm{~F}} / \mathrm{kWh}$
\end{tabular} \\
\hline \multirow[t]{2}{*}{$\begin{array}{c}\text { Free Field } \\
\text { Dose }\end{array}$} & Outside & 1.36 & 1.34 & 1.36 & 1.34 \\
\hline & FF Box & 0.35 & 0.36 & 0.35 & 0.32 \\
\hline \multirow[t]{7}{*}{$\begin{array}{l}\text { Dose in } \\
\text { Phantom }\end{array}$} & $\mathrm{MH}$ & 2.01 & 0.88 & 2.05 & 0.76 \\
\hline & $\mathrm{MG}$ & 2.08 & 0.83 & 1.88 & 0.71 \\
\hline & $\mathrm{LC}$ & 1.93 & 0.62 & 1.66 & 0.52 \\
\hline & LW & 1.58 & 0.44 & 1.28 & 0.36 \\
\hline & RW. & 1.68 & 0.48 & 1.70 & 0.46 \\
\hline & $\mathrm{FB}$ & 2.04 & 0.65 & 1.77 & 0.56 \\
\hline & $\mathrm{BB}$ & 1.55 & 0.60 & 1.79 & 0.55 \\
\hline Average & & 1.84 & 0.64 & 1.73 & 0.56 \\
\hline STD & & 0.23 & 0.16 & 0.24 & 0.14 \\
\hline
\end{tabular}


Table 14. SAIC Calculations of Gamma-Ray Dose Rate in the Free-Field and as a Function of Position on the RT-200 Humanoid Phantom.

\begin{tabular}{|c|c|c|c|c|c|}
\hline Run Number & & $129 / 130$ & $127 / 128$ & $132 / 133 / 134$ & $135 / 136$ \\
\hline \multirow[t]{2}{*}{ Run Length } & & $50 \mathrm{kWh}$ & $50 \mathrm{kWh}$ & $35.2 \mathrm{kWh}$ & $23.8 \mathrm{kWh}$ \\
\hline & & $\begin{array}{c}\text { FF } \\
\text { Facing } \\
\operatorname{mrad}_{\mathrm{Ti}} \mathrm{kWh} \\
\end{array}$ & \begin{tabular}{c} 
In-Box \\
Facing \\
\hdashline $\operatorname{mrad}_{\mathrm{Ti}} / \mathrm{kWh}$ \\
\end{tabular} & \begin{tabular}{c} 
FF \\
Right Side \\
\hdashline $\mathrm{mrad}_{\mathrm{Ti}} / \mathrm{kWh}$ \\
\end{tabular} & $\begin{array}{c}\text { In-Box } \\
\text { Right Side } \\
\operatorname{mrad}_{\mathrm{Ti}} / \mathrm{kWh}\end{array}$ \\
\hline \multirow[t]{2}{*}{$\begin{array}{c}\text { Free Field } \\
\text { Dose }\end{array}$} & Outsidie & 1.33 & 1.27 & 1.34 & 1.33 \\
\hline & FF Box & 0.36 & 0.37 & 0.32 & 0.36 \\
\hline \multirow[t]{7}{*}{$\begin{array}{l}\text { Dose in } \\
\text { Phantom }\end{array}$} & $\mathrm{MH}$ & 1.89 & 0.87 & 1.96 & 0.77 \\
\hline & $\mathrm{MG}$ & 1.89 & 0.87 & 1.73 & 0.82 \\
\hline & $\mathrm{LC}$ & 1.72 & 0.68 & 1.56 & 0.57 \\
\hline & LW & 1.51 & 0.55 & 1.19 & 0.48 \\
\hline & RW & 1.54 & 0.51 & 1.61 & 0.50 \\
\hline & $\mathrm{FB}$ & 1.85 & 0.73 & 1.68 & 0.50 \\
\hline & $\mathrm{BB}$ & 1.49 & 0.54 & 1.70 & 0.57 \\
\hline Average & & 1.70 & 0.68 & 1.63 & 0.60 \\
\hline STD & & 0.18 & 0.15 & 0.23 & 0.14 \\
\hline
\end{tabular}


Table 15. SAIC Calculations of Gamma-Ray Dose Rate in the Free-Field and as a Function of Position on the RT-200 Humanoid Phantom.

\begin{tabular}{|c|c|c|c|c|c|}
\hline Run Number & & $129 / 130$ & $127 / 128$ & $132 / 133 / 134$ & $135 / 136$ \\
\hline \multirow[t]{2}{*}{ Run Length } & & $50 \mathrm{kWh}$ & $50 \mathrm{kWh}$ & $35.2 \mathrm{kWh}$ & $23.8 \mathrm{kWh}$ \\
\hline & & \begin{tabular}{c} 
FF \\
Facing \\
\hdashline $\mathrm{mrad}_{\mathrm{CaF}} / \mathrm{kWh}$ \\
\end{tabular} & \begin{tabular}{c}
$\begin{array}{l}\text { In-Box } \\
\text { Facing }\end{array}$ \\
\hdashline $\mathrm{mrad}_{\mathrm{CAF}} / \mathrm{kWh}$ \\
\end{tabular} & \begin{tabular}{c} 
FF \\
Right Side \\
\hdashline $\operatorname{mrad}_{\mathrm{CaF}} / \mathrm{kWh}$ \\
\end{tabular} & \begin{tabular}{c}
$\begin{array}{c}\text { In-Box } \\
\text { Right Side }\end{array}$ \\
\hdashline $\operatorname{mrad}_{\mathrm{CaF}} / \mathrm{kWh}$ \\
\end{tabular} \\
\hline \multirow[t]{2}{*}{$\begin{array}{l}\text { Free Field } \\
\text { Dase }\end{array}$} & Outside & 1.46 & 1.41 & 1.45 & 1.50 \\
\hline & FF Box & 0.31 & 0.37 & 0.32 & 0.35 \\
\hline \multirow[t]{7}{*}{$\begin{array}{l}\text { Dose in } \\
\text { Phantom }\end{array}$} & $\mathrm{MH}$ & 2.16 & 0.84 & 2.24 & 0.73 \\
\hline & $\mathrm{MG}$ & 2.26 & 0.85 & 2.08 & 0.80 \\
\hline & LC & 1.96 & 0.65 & 1.76 & 0.56 \\
\hline & LW & 1.70 & 0.54 & 1.37 & 0.47 \\
\hline & RW & 1.73 & 0.50 & 1.80 & 0.49 \\
\hline & FB & 2.08 & 0.72 & 1.88 & 0.49 \\
\hline & $\mathrm{BB}$ & 1.72 & 0.52 & 1.94 & 0.55 \\
\hline Average & & 1.94 & 0.66 & 1.87 & 0.58 \\
\hline STD & & 0.23 & 0.15 & 0.27 & 0.13 \\
\hline
\end{tabular}


Table 16. Ratios of the Calculated Gamma-Ray Doses

(Dose rates in $\operatorname{mrad}(\mathrm{Ti}) / \mathrm{kWh}$.)

\begin{tabular}{|c|c|c|c|c|c|}
\hline \multirow[t]{2}{*}{$\begin{array}{l}\text { Run Number } \\
\text { Run Length }\end{array}$} & & $\begin{array}{l}129 / 130 \\
50 \mathrm{kWh} \\
\end{array}$ & $\begin{array}{l}127 / 128 \\
50 \mathrm{kWh} \\
\end{array}$ & $\begin{array}{c}132 / 133 / 134 \\
35.2 \mathrm{kWh} \\
\end{array}$ & $\begin{array}{r}135 / 136 \\
23.8 \mathrm{kWh} \\
\end{array}$ \\
\hline & & $\begin{array}{c}\text { FF } \\
\text { Facing } \\
\text { ORNL/SAIC }\end{array}$ & $\begin{array}{c}\text { In-1Box } \\
\text { Facing } \\
\text { ORNL/SAIC }\end{array}$ & $\begin{array}{c}\text { FF } \\
\text { Right Side } \\
\text { ORNLSAIC }\end{array}$ & $\begin{array}{c}\text { In-Box } \\
\text { Right Side } \\
\text { ORNL/SAIC }\end{array}$ \\
\hline \multicolumn{6}{|l|}{ Free Field Dase } \\
\hline & Outside & 1.01 & 1.05 & 1.00 & 0.99 \\
\hline & FF Box & 1.06 & 1.03 & 1.19 & 0.97 \\
\hline \multirow[t]{7}{*}{$\begin{array}{l}\text { Doce in } \\
\text { Phantom }\end{array}$} & MH & 1.02 & 1.07 & 1.01 & 1.05 \\
\hline & MG & 1.02 & 0.98 & 1.00 & 0.89 \\
\hline & LC & 1.07 & 0.97 & 1.01 & 0.96 \\
\hline & LW & 1.00 & 0.85 & 1.00 & 0.81 \\
\hline & RW & 1.05 & 1.02 & 1.01 & 0.98 \\
\hline & $\mathrm{FB}$ & 1.04 & 0.95 & 1.00 & 1.16 \\
\hline & $\mathrm{BB}$ & 0.99 & 1.17 & 1.01 & 1.02 \\
\hline
\end{tabular}

Table 17. Ratios of the Calculated Gamma-Ray Doses

(Dase rates in $\operatorname{mrad}\left(\mathrm{CaF}_{2}\right) / \mathrm{kWh}$.)

\begin{tabular}{|c|c|c|c|c|c|}
\hline $\begin{array}{l}\text { Run Number } \\
\text { Run Length }\end{array}$ & & $\begin{array}{l}129 / 130 \\
50 \mathrm{kWh}\end{array}$ & $\begin{array}{l}127 / 128 \\
50 \mathrm{kWh}\end{array}$ & $\begin{array}{c}132,133,134 \\
35.2 \mathrm{kWh}\end{array}$ & $\begin{array}{c}135 / 136 \\
23.8 \mathrm{kWh}\end{array}$ \\
\hline & & $\begin{array}{c}\text { FF } \\
\text { Facing } \\
\text { ORNLSAIC }\end{array}$ & $\begin{array}{c}\text { In-Bkx } \\
\text { Facing } \\
\text { ORNL.SAIC }\end{array}$ & \begin{tabular}{c} 
FF \\
Right Side \\
\hdashline ORNL/SAIC
\end{tabular} & $\begin{array}{c}\begin{array}{c}\text { In-Bou } \\
\text { Right Side }\end{array} \\
\text { ORNL/SAIC }\end{array}$ \\
\hline \multicolumn{6}{|l|}{ Free Fueld Dose } \\
\hline & Outside & 0.93 & 0.95 & 0.94 & 0.89 \\
\hline & FF Box & 1.13 & 0.97 & 1.09 & 0.91 \\
\hline \multirow[t]{7}{*}{$\begin{array}{l}\text { Dose in } \\
\text { Phantom }\end{array}$} & MH & 0.93 & 1.05 & 0.92 & 1.04 \\
\hline & $\mathrm{MG}$ & 0.92 & 0.98 & 0.90 & 0.89 \\
\hline & LC & 0.98 & 0.95 & 0.94 & 0.93 \\
\hline & LW & 0.93 & 0.81 & 0.93 & 0.77 \\
\hline & RW & 0.97 & 0.96 & 0.94 & 0.94 \\
\hline & FB & 0.98 & 0.90 & 0.94 & 1.14 \\
\hline & $\mathrm{BB}$ & 0.90 & 1.15 & 0.92 & 1.00 \\
\hline
\end{tabular}


Table 18. ORNL Calculations of Neutron Dose Rate in the Free-Field and as a Function of Position on the RT-200 Humanoid Phantom.

\begin{tabular}{|c|c|c|c|c|c|}
\hline Run Number & & 120 & $122 / 123$ & 119 & $124 / 125$ \\
\hline & & \begin{tabular}{c}
$\mathbf{F F}$ \\
Facing \\
\hdashline $\operatorname{mrad}_{\mathrm{Ti}} / \mathrm{kWh}$ \\
\end{tabular} & $\begin{array}{c}\begin{array}{c}\text { In-Box } \\
\text { Facing }\end{array} \\
\operatorname{mrad}_{\mathrm{Ti}} / \mathrm{kWh} \\
\end{array}$ & \begin{tabular}{c} 
FF \\
Right Side \\
\hdashline $\mathrm{mrad}_{\mathrm{Ti}} / \mathrm{kWh}$ \\
\end{tabular} & \begin{tabular}{c}
$\begin{array}{c}\text { In-Box } \\
\text { Right Side }\end{array}$ \\
\hdashline $\mathrm{mrad}_{\mathrm{T} /} / \mathrm{kWh}$ \\
\end{tabular} \\
\hline \multirow[t]{2}{*}{$\begin{array}{l}\text { Free Field } \\
\text { Dose }\end{array}$} & Outside & 4.90 & 4.90 & 4.90 & 4.90 \\
\hline & FF Box & 3.03 & 2.82 & 3.03 & 2.82 \\
\hline \multirow[t]{7}{*}{$\begin{array}{l}\text { Dose in } \\
\text { Phantom }\end{array}$} & $\mathrm{MH}$ & 1.20 & 0.41 & 1.38 & 0.44 \\
\hline & MG & 0.74 & 0.20 & 0.44 & 0.16 \\
\hline & $1 . C$ & 4.52 & 2.35 & 3.17 & 1.91 \\
\hline & L.W & 4.35 & 2.45 & 2.34 & 1.97 \\
\hline & $\mathrm{F}: \mathrm{W}$ & 4.40 & 2.36 & 4.47 & 2.49 \\
\hline & $\mathrm{FB}$ & 4.47 & 2.27 & 3.39 & 1.90 \\
\hline & $\mathrm{BBB}$ & 1.62 & 1.47 & 3.29 & 1.90 \\
\hline Average & & 3.04 & 1.63 & 2.64 & 1.54 \\
\hline STD & & 1.76 & 1.03 & 1.36 & 0.88 \\
\hline
\end{tabular}


Table 19. SAIC Calculations of Neutron Dose Rate in the Free-Field and as a Function of Position on the RT-200 Humanoid Phantom.

\begin{tabular}{|c|c|c|c|c|c|}
\hline Run Number & & 120 & $122 / 123$ & 119 & $124 / 125$ \\
\hline & & $\begin{array}{c}\text { FF } \\
\text { Facing } \\
\text { mrad }_{\mathrm{Ti}} / \mathrm{kWh} \\
\end{array}$ & $\begin{array}{c}\text { In-Box } \\
\text { Facing } \\
\mathrm{mrad}_{\mathrm{Ti}} / \mathrm{kWh} \\
\end{array}$ & \begin{tabular}{c} 
FF \\
Right Side \\
\hdashline $\mathrm{mrad}_{\mathrm{T}} / \mathrm{kWh}$ \\
\end{tabular} & \begin{tabular}{c}
$\begin{array}{c}\text { In-Box } \\
\text { Right Side }\end{array}$ \\
\hdashline $\operatorname{mrad}_{\mathrm{Ti}} / \mathrm{kWh}$
\end{tabular} \\
\hline \multirow[t]{2}{*}{$\begin{array}{l}\text { Free Field } \\
\text { Dose }\end{array}$} & Outside & 5.01 & 5.19 & 5.02 & 5.29 \\
\hline & FF Box & 2.99 & 2.86 & 3.00 & 2.91 \\
\hline \multirow[t]{7}{*}{$\begin{array}{l}\text { Dose in } \\
\text { Phantom }\end{array}$} & $\mathrm{MH}$ & 1.10 & 0.45 & 1.27 & 0.53 \\
\hline & MG & 0.83 & 0.22 & 0.45 & 0.18 \\
\hline & $\mathrm{LC}$ & 4.58 & 2.50 & 3.02 & 2.17 \\
\hline & LW & 4.09 & 2.44 & 2.27 & 1.91 \\
\hline & RW & 4.12 & 2.49 & 4.63 & 2.76 \\
\hline & FB & 4.49 & 2.32 & 3.37 & 2.08 \\
\hline & $\mathrm{BB}$ & 1.57 & 1.63 & 2.79 & 2.17 \\
\hline Average & & 2.97 & 1.72 & 2.54 & 1.69 \\
\hline STD & & 1.71 & 1.00 & 1.38 & 0.95 \\
\hline
\end{tabular}


Table 20. Ratios of the Calculated Neutron Doses (Dose rates in $\operatorname{mrad}(\mathrm{Ti}) / \mathrm{kWh}$.)

\begin{tabular}{|c|c|c|c|c|c|}
\hline Run Number & & 120 & $122 / 123$ & 119 & $124 / 125$ \\
\hline & & \begin{tabular}{c}
$\begin{array}{c}\text { FF } \\
\text { Facing }\end{array}$ \\
\hdashline ORNL/SAIC
\end{tabular} & $\begin{array}{c}\begin{array}{c}\text { In-Box } \\
\text { Facing }\end{array} \\
\text { ORNL/SAIC }\end{array}$ & $\begin{array}{c}\text { FF } \\
\text { Right Side } \\
\text { ORNL/SAIC }\end{array}$ & $\begin{array}{c}\text { In-Box } \\
\text { Right Side } \\
\text { ORNL/SAIC }\end{array}$ \\
\hline \multirow[t]{2}{*}{$\begin{array}{l}\text { Free Field } \\
\text { Dase }\end{array}$} & Outside & 0.98 & 0.94 & 0.98 & 0.93 \\
\hline & FF Box & 1.01 & 0.99 & 1.01 & 0.97 \\
\hline \multirow[t]{7}{*}{$\begin{array}{l}\text { Dose in } \\
\text { Phantom }\end{array}$} & MH & 1.09 & 0.91 & 1.08 & 0.83 \\
\hline & MG & 0.89 & 0.90 & 0.98 & 0.89 \\
\hline & LC & 0.98 & 0.94 & 1.05 & 0.88 \\
\hline & LW & 1.06 & 1.00 & 1.03 & 1.03 \\
\hline & RW & 0.99 & 0.95 & 0.97 & 0.91 \\
\hline & FB & 0.99 & 0.95 & 0.97 & 0.91 \\
\hline & $\mathrm{BB}$ & 1.03 & 0.90 & 1.17 & 0.88 \\
\hline
\end{tabular}


Table 21. Measured and Calculated Gamma-Ray Doses and Reduction Factors Free-Field/Phantom Facing Reactor

Comparisons with APRF TLD Measurements

Duses in $\operatorname{mrad}_{\mathrm{Ti}} / \mathrm{kWh}$.

\begin{tabular}{|c|c|c|c|c|c|c|c|c|c|c|}
\hline & \multicolumn{5}{|c|}{ Run Number $129 / 130$} & \multicolumn{2}{|c|}{$50 \mathrm{kWh}$} & \multirow[b]{2}{*}{$\mathrm{C} / \mathrm{M}$} & \multirow[b]{2}{*}{ SAI } & \multirow[b]{2}{*}{$\mathrm{C} / \mathrm{M}$} \\
\hline & Dose & OR & $\mathrm{C} / \mathrm{M}$ & SAI & $\mathrm{C} / \mathrm{M}$ & $\mathrm{RF}$ & OR & & & \\
\hline \multicolumn{11}{|c|}{ Free-Field Doses } \\
\hline \multirow[t]{2}{*}{ Out } & 1.70 & 1.34 & 0.79 & 1.33 & 0.78 & & & & & \\
\hline & & & & & & 5.48 & 3.53 & 0.64 & 3.69 & 0.67 \\
\hline Box & 0.31 & 0.38 & 1.23 & 0.36 & 1.16 & & & & & \\
\hline \multicolumn{11}{|c|}{ Doses in Phantom } \\
\hline MH & 2.15 & 1.93 & 0.90 & 1.89 & 0.88 & 0.79 & 0.69 & 0.87 & 0.70 & 0.89 \\
\hline MG & 2.14 & 1.92 & 0.90 & 1.89 & 0.88 & 0.79 & 0.70 & 0.89 & 0.70 & 0.89 \\
\hline $\mathrm{LC}$ & 2.08 & 1.84 & 0.88 & 1.72 & 0.83 & 0.82 & 0.73 & 0.89 & 0.77 & 0.94 \\
\hline $\mathrm{LW}$ & 1.83 & 1.51 & 0.83 & 1.51 & 0.83 & 0.93 & 0.88 & 0.95 & 0.88 & 0.95 \\
\hline RW & 1.95 & 1.61 & 0.83 & 1.54 & 0.80 & 0.87 & 0.83 & 0.95 & 0.86 & 0.99 \\
\hline $\mathrm{FB}$ & 2.08 & 1.93 & 0.93 & 1.85 & 0.89 & 0.82 & 0.69 & 0.84 & 0.72 & 0.88 \\
\hline $\mathrm{BB}$ & 1.68 & 1.48 & 0.88 & 1.49 & 0.89 & 1.01 & 0.91 & 0.90 & 0.89 & 0.88 \\
\hline AVG & 1.99 & 1.75 & 0.88 & 1.70 & 0.86 & 0.86 & 0.78 & 0.90 & 0.79 & 0.92 \\
\hline STD & 0.18 & 0.20 & 0.04 & 0.18 & 0.04 & 0.08 & 0.10 & 0.04 & 0.09 & 0.04 \\
\hline
\end{tabular}


Table 22. Measured and Calculated Gamma-Ray Doses and Reduction Factors In-Box/Phantom Facing Reactor

Comparisons with APRF TLD Measurements

Doses in $\operatorname{mrad}_{\mathrm{Tr}} / \mathrm{kWh}$.

\begin{tabular}{|c|c|c|c|c|c|c|c|c|c|c|}
\hline & \multicolumn{5}{|c|}{ Run Number $127 / 128$} & \multicolumn{5}{|c|}{$50 \mathrm{kWh}$} \\
\hline & Dose & OR & $\mathrm{C} / \mathrm{M}$ & SAI & $\mathrm{C} / \mathrm{M}$ & RF & OR & $\mathrm{C} / \mathrm{M}$ & SAI & $\mathrm{C} / \mathrm{M}$ \\
\hline \multicolumn{11}{|c|}{ Free-Field Doses } \\
\hline \multirow[t]{2}{*}{ Out } & 1.69 & 1.33 & 0.79 & 1.27 & 0.75 & & & & & \\
\hline & & & & & & 4.33 & 3.50 & 0.81 & 3.43 & 0.79 \\
\hline Box & 0.39 & 0.38 & 0.97 & 0.37 & 0.95 & & & & & \\
\hline \multicolumn{11}{|c|}{ Doses in Phantom } \\
\hline $\mathrm{MH}$ & 0.91 & 0.93 & 1.02 & 0.87 & 0.96 & 1.86 & 1.43 & 0.77 & 1.46 & 0.78 \\
\hline $\mathrm{MG}$ & 0.79 & 0.85 & 1.08 & 0.87 & 1.10 & 2.14 & 1.56 & 0.73 & 1.46 & 0.68 \\
\hline LC & 0.59 & 0.66 & 1.12 & 0.68 & 1.15 & 2.86 & 2.01 & 0.70 & 1.87 & 0.65 \\
\hline LW & 0.49 & 0.47 & 0.96 & 0.55 & 1.12 & 3.45 & 2.81 & 0.81 & 2.31 & 0.67 \\
\hline RW & 0.52 & 0.52 & 1.00 & 0.51 & 0.98 & 3.25 & 2.58 & 0.79 & 2.49 & 0.77 \\
\hline FB & 0.61 & 0.69 & 1.13 & 0.73 & 1.20 & 2.77 & 1.94 & 0.70 & 1.74 & 0.63 \\
\hline $\mathrm{BB}$ & 0.56 & 0.63 & 1.13 & 0.54 & 0.96 & 3.02 & 2.10 & 0.70 & 2.35 & 0.78 \\
\hline AVG & 0.64 & 0.68 & 1.06 & 0.68 & 1.07 & 2.76 & 2.06 & 0.74 & 1.95 & 0.71 \\
\hline STD & 0.15 & 0.17 & 0.07 & 0.15 & 0.10 & 0.58 & 0.50 & 0.05 & 0.43 & 0.07 \\
\hline
\end{tabular}


Table 23. Measured and Calculated Gamma-Ray Doses and Reduction Factors

Free-Field/Right-Side Facing Reactor

Comparisons with APRF TLD Measurements

Doses in $\operatorname{mrad}_{\mathrm{T}} / \mathrm{kWh}$.

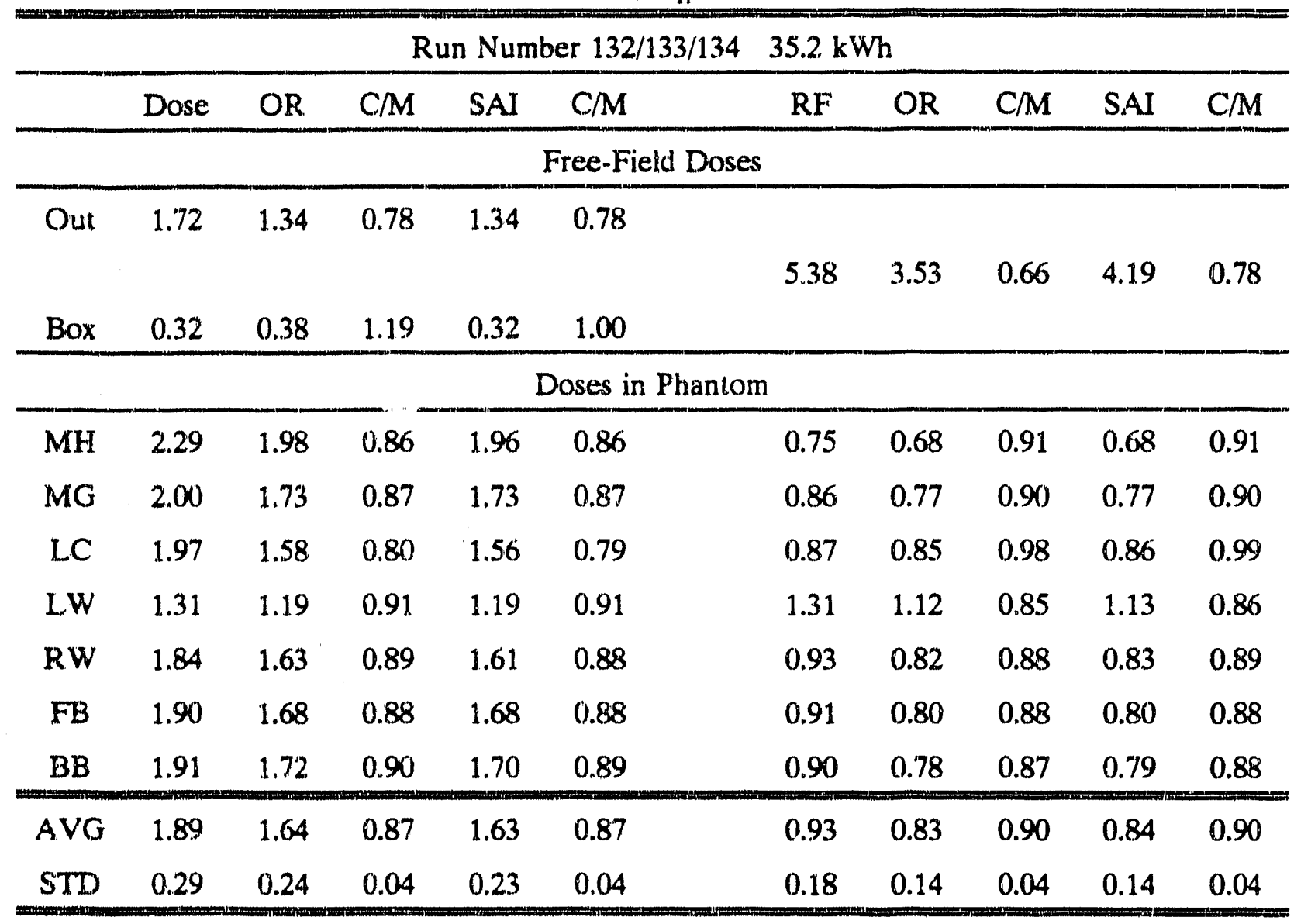


Table 24. Measured and Calculated Gamma-Ray Doses and Reduction Factors In-Box/Right-Side Facing Reactor

Comparisons with APRF TLD Measurements

Doses in $\operatorname{mrad}_{\mathrm{Ti}} / \mathrm{kWh}$.

\begin{tabular}{|c|c|c|c|c|c|c|c|c|c|c|}
\hline & \multicolumn{5}{|c|}{ Run Number $135 / 136$} & \multicolumn{2}{|c|}{$23.8 \mathrm{kWh}$} & \multirow[b]{2}{*}{$\mathrm{C} / \mathrm{M}$} & \multirow[b]{2}{*}{ SAI } & \multirow[b]{2}{*}{$\mathrm{C} / \mathrm{M}$} \\
\hline & Dose & OR & $\mathrm{C} / \mathrm{M}$ & SAI & $\mathrm{C} / \mathrm{M}$ & $\mathrm{RF}$ & OR & & & \\
\hline \multicolumn{11}{|c|}{ Free-Field Doses } \\
\hline \multirow[t]{2}{*}{ Out } & 1.71 & 1.32 & 0.77 & 1.33 & 0.78 & & & & & \\
\hline & & & & & & 5.18 & 3.77 & 0.73 & 3.69 & 0.71 \\
\hline Box & 0.33 & 0.35 & 1.06 & 0.36 & 1.09 & & & & & \\
\hline \multicolumn{11}{|c|}{ Doses in Phantom } \\
\hline MH & 0.74 & 0.81 & 1.09 & 0.77 & 1.04 & 2.31 & 1.64 & 0.71 & 1.73 & 0.75 \\
\hline MG & 0.72 & 0.73 & 1.01 & 0.82 & 1.14 & 2.38 & 1.80 & 0.76 & 1.62 & 0.68 \\
\hline LC & 0.49 & 0.55 & 1.12 & 0.57 & 1.16 & 3.49 & 2.39 & 0.68 & 2.33 & 0.67 \\
\hline LW & 0.37 & 0.39 & 1.05 & 0.48 & 1.30 & 4.62 & 3.38 & 0.73 & 2.77 & 0.60 \\
\hline RW & 0.45 & 0.49 & 1.09 & 0.50 & 1.11 & 3.80 & 2.70 & 0.71 & 2.66 & 0.70 \\
\hline FB & 0.49 & 0.58 & 1.18 & 0.50 & 1.02 & 3.49 & 2.26 & 0.65 & 2.66 & 0.76 \\
\hline $\mathrm{BB}$ & 0.52 & 0.58 & 1.12 & 0.57 & 1.10 & 3.29 & 2.26 & 0.69 & 2.33 & 0.71 \\
\hline$A V G$ & 0.54 & 0.59 & 1.09 & 0.60 & 1.12 & 3.34 & 2.35 & 0.70 & 2.30 & 0.70 \\
\hline STD & 0.14 & 0.14 & 0.05 & 0.14 & 0.09 & 0.80 & 0.58 & 0.04 & 0.46 & 0.05 \\
\hline
\end{tabular}


Table 25. Measured and Calculated Gamma-Ray Doses and Reduction Factors

Free-Field/Phantom Facing Reactor

Comparisons with HDL TLD Measurements

Doses in $\operatorname{mrad}_{\mathrm{CAF}} / \mathrm{kWh}$.

\begin{tabular}{|c|c|c|c|c|c|c|c|c|c|c|}
\hline & \multicolumn{5}{|c|}{ Run Number $129 / 130$} & \multicolumn{2}{|c|}{$50 \mathrm{kWh}$} & \multirow[b]{2}{*}{$\mathrm{C} / \mathrm{M}$} & \multirow[b]{2}{*}{ SAI } & \multirow[b]{2}{*}{$\mathrm{C} / \mathrm{M}$} \\
\hline & Dose & OR & $\mathrm{C} / \mathrm{M}$ & SAI & $\mathrm{C} / \mathrm{M}$ & RF & OR & & & \\
\hline \multicolumn{11}{|c|}{ Free-Field Doses } \\
\hline \multirow[t]{2}{*}{ Out } & 1.33 & 1.36 & 1.02 & 1.46 & 1.10 & & & & & \\
\hline & & & & & & 4.59 & 3.89 & 0.85 & 4.71 & 1.03 \\
\hline Box & 0.29 & 0.35 & 1.21 & 0.31 & 1.07 & & & & & \\
\hline \multicolumn{11}{|c|}{ Doses in Phantom } \\
\hline MH & 1.90 & 2.01 & 1.06 & 2.16 & 1.14 & 0.70 & 0.68 & 0.97 & 0.68 & 0.97 \\
\hline MG & 1.91 & 2.08 & 1.09 & 2.26 & 1.18 & 0.70 & 0.65 & 0.93 & 0.65 & 0.93 \\
\hline $\mathrm{LC}$ & 1.90 & 1.93 & 1.02 & 1.96 & 1.03 & 0.70 & 0.70 & 1.00 & 0.74 & 1.06 \\
\hline LW & 1.74 & 1.58 & 0.91 & 1.70 & 0.98 & 0.76 & 0.86 & 1.13 & 0.86 & 1.13 \\
\hline RW & 1.91 & 1.68 & 0.88 & 1.73 & 0.91 & 0.70 & 0.81 & 1.16 & 0.84 & 1.20 \\
\hline FB & 2.10 & 2.04 & 0.97 & 2.08 & 0.99 & 0.63 & 0.67 & 1.06 & 0.70 & 1.11 \\
\hline $\mathrm{BB}$ & 1.85 & 1.55 & 0.84 & 1.72 & 0.93 & 0.72 & 0.88 & 1.22 & 0.85 & 1.18 \\
\hline AVG & 1.90 & 1.84 & 0.97 & 1.94 & 1.02 & 0.70 & 0.75 & 1.07 & 0.76 & 1.08 \\
\hline STD & 0.11 & 0.23 & 0.09 & 0.23 & 0.10 & 0.04 & 0.10 & 0.11 & 0.19 & 0.10 \\
\hline
\end{tabular}


Table 26. Measured and Calculated Gamma-Ray Doses and Reduction Factors

In-Box/Phantom Facing Reactor

Comparisons with HDL TLD Measurements

Doses in $\operatorname{mrad}_{\mathrm{C}, \mathrm{p}} / \mathrm{kWh}$.

\begin{tabular}{|c|c|c|c|c|c|c|c|c|c|c|}
\hline & \multicolumn{5}{|c|}{ Run Number $127 / 128$} & \multicolumn{2}{|c|}{$50 \mathrm{kWh}$} & \multirow[b]{2}{*}{$\mathrm{C} / \mathrm{M}$} & \multirow[b]{2}{*}{ SAI } & \multirow[b]{2}{*}{$\mathrm{C} / \mathrm{M}$} \\
\hline & Dose & OR & $\mathrm{C} / \mathrm{M}$ & SAI & $\mathrm{C} / \mathrm{M}$ & $\mathrm{RF}$ & OR & & & \\
\hline \multicolumn{11}{|c|}{ Free-Field Doses } \\
\hline \multirow[t]{2}{*}{ Out } & 1.32 & 1.34 & 1.02 & 1.41 & 1.07 & & & & & \\
\hline & & & & & & 4.00 & 3.72 & 0.93 & 3.81 & 0.95 \\
\hline Box & 0.33 & 0.36 & 1.09 & 0.37 & 1.12 & & & & & \\
\hline \multicolumn{11}{|c|}{ Doses in Phantom } \\
\hline MH & 0.66 & 0.88 & 1.33 & 0.84 & 1.27 & 2.00 & 1.53 & 0.77 & 1.68 & 0.84 \\
\hline MG & 0.63 & 0.83 & 1.32 & 0.85 & 1.35 & 2.10 & 1.62 & 0.77 & 1.66 & 0.79 \\
\hline LC & 0.53 & 0.62 & 1.17 & 0.65 & 1.23 & 2.49 & 2.17 & 0.87 & 2.17 & 0.87 \\
\hline LW & 0.43 & 0.44 & 1.02 & 0.54 & 1.26 & 3.07 & 3.05 & 0.99 & 2.61 & 0.85 \\
\hline RW & 0.47 & 0.48 & 1.02 & 0.50 & 1.06 & 2.81 & 2.77 & 0.99 & 2.82 & 1.00 \\
\hline FB & 0.49 & 0.65 & 1.33 & 0.72 & 1.47 & 2.69 & 2.05 & 0.76 & 1.96 & 0.73 \\
\hline BB & 0.52 & 0.60 & 1.15 & 0.52 & 1.00 & 2.54 & 2.24 & 0.88 & 2.71 & 1.07 \\
\hline AVG & 0.53 & 0.64 & 1.19 & 0.66 & 1.23 & 2.53 & 2.20 & 0.86 & 2.23 & 0.88 \\
\hline STD & 0.08 & 0.16 & 0.14 & 0.15 & 0.16 & 0.38 & 0.56 & 0.10 & 0.49 & 0.12 \\
\hline
\end{tabular}


Table 27. Measured and Calculated Gamma-Ray Duses and Reduction Factors Free-Field/Right-Side Facing Reactor Comparisons with HDL TLD Measurements Doses in $\operatorname{mrad}_{\mathrm{CaF}} / \mathrm{kWh}$.

\begin{tabular}{|c|c|c|c|c|c|c|c|c|c|c|}
\hline \multicolumn{11}{|c|}{ Run Number $132 / 133 / 134 \quad 35.2 \mathrm{kWh}$} \\
\hline & Dose & OR & $\mathrm{C} / \mathrm{M}$ & SAI & $\mathrm{C} / \mathrm{M}$ & RF & OR & $\mathrm{C} / \mathrm{M}$ & SAI & $\mathrm{C} / \mathrm{M}$ \\
\hline \multicolumn{11}{|c|}{ Free-Field Doses } \\
\hline \multirow[t]{2}{*}{ Out } & 1.31 & 1.36 & 1.04 & 1.45 & 1.11 & & & & & \\
\hline & & & & & & 4.37 & 3.89 & 0.89 & 4.53 & 1.04 \\
\hline Box & 0.30 & 0.35 & 1.17 & 0.32 & 1.07 & & & & & \\
\hline \multicolumn{11}{|c|}{ Doses in Phantom } \\
\hline MH & 1.70 & 2.05 & 1.21 & 2.24 & 1.32 & 0.77 & 0.66 & 0.86 & 0.65 & 0.84 \\
\hline MG & 1.53 & 1.88 & 1.23 & 2.08 & 1.36 & 0.86 & 0.72 & 0.84 & 0.70 & 0.81 \\
\hline LC & 1.45 & 1.66 & 1.14 & 1.76 & 1.21 & 0.90 & 0.82 & 0.91 & 0.82 & 0.91 \\
\hline LW & 1.12 & 1.28 & 1.14 & 1.37 & 1.22 & 1.17 & 1.06 & 0.91 & 1.06 & 0.91 \\
\hline RW & 1.56 & 1.70 & 1.09 & 1.80 & 1.15 & 0.84 & 0.80 & 0.95 & 0.81 & 0.96 \\
\hline FB & 1.47 & 1.77 & 1.20 & 1.88 & 1.28 & 0.89 & 0.76 & 0.85 & 0.77 & 0.87 \\
\hline $\mathrm{BB}$ & 1.44 & 1.79 & 1.24 & 1.94 & 1.35 & 0.91 & 0.76 & 0.84 & 0.75 & 0.82 \\
\hline $\mathrm{AVG}$ & 1.47 & 1.73 & 1.18 & 1.87 & 1.27 & 0.91 & 0.80 & 0.88 & 0.79 & 0.87 \\
\hline STD & 0.18 & 0.24 & 0.06 & 0.27 & 0.08 & 0.13 & 0.13 & 0.04 & 0.13 & 0.06 \\
\hline
\end{tabular}


Table 28. Measured and Calculated Gamma-Ray Doses and Reduction Factors

In-Box/Right-Side Facing Reactor

Comparisons with HDL TLD Measurements

Doses in $\mathrm{mrad}_{\mathrm{CaF}} / \mathrm{kWh}$.

\begin{tabular}{|c|c|c|c|c|c|c|c|c|c|c|}
\hline & \multicolumn{5}{|c|}{ Run Number $135 / 136$} & \multicolumn{2}{|c|}{$23.8 \mathrm{kWh}$} & \multirow[b]{2}{*}{$\mathrm{C} / \mathrm{M}$} & \multirow[b]{2}{*}{ SAI } & \multirow[b]{2}{*}{$\mathrm{C} / \mathrm{M}$} \\
\hline & Dose & OR & $\mathrm{C} / \mathrm{M}$ & SAI & $\mathrm{C} / \mathrm{M}$ & $\mathrm{RF}$ & OR & & & \\
\hline \multicolumn{11}{|c|}{ Free-Field Doses } \\
\hline \multirow[t]{2}{*}{ Out } & 1.31 & 1.34 & 1.02 & 1.50 & 1.15 & & & & & \\
\hline & & & & & & 4.85 & 4.19 & 0.86 & 4.29 & 0.88 \\
\hline Box & 0.27 & 0.32 & 1.19 & 0.35 & 1.30 & & & & & \\
\hline \multicolumn{11}{|c|}{ Doses in Phantom } \\
\hline $\mathrm{MH}$ & 0.64 & 0.76 & 1.19 & 0.73 & 1.14 & 2.05 & 1.76 & 0.86 & 2.05 & 1.00 \\
\hline MG & 0.57 & 0.71 & 1.25 & 0.80 & 1.40 & 2.30 & 1.88 & 0.82 & 1.88 & 0.82 \\
\hline LC & 0.53 & 0.52 & 0.98 & 0.56 & 1.06 & 2.47 & 2.59 & 1.05 & 2.68 & 1.08 \\
\hline L.W & 0.38 & 0.36 & 0.95 & 0.47 & 1.24 & 3.45 & 3.69 & 1.07 & 3.19 & 0.93 \\
\hline RW & 0.27 & 0.46 & 1.70 & 0.49 & 1.81 & 4.85 & 2.92 & 0.60 & 3.06 & 0.63 \\
\hline $\mathrm{FB}$ & 0.41 & 0.56 & 1.37 & 0.49 & 1.20 & 3.20 & 2.41 & 0.75 & 3.06 & 0.96 \\
\hline $\mathrm{BB}$ & 0.40 & 0.55 & 1.38 & 0.55 & 1.38 & 3.28 & 2.44 & 0.74 & 2.73 & 0.83 \\
\hline$A V G$ & 0.46 & 0.56 & 1.26 & 0.58 & 1.32 & 3.09 & 2.53 & 0.84 & 2.66 & 0.89 \\
\hline STD & 0.13 & 0.14 & 0.26 & 0.13 & 0.25 & 0.95 & 0.65 & 0.17 & 0.51 & 0.15 \\
\hline
\end{tabular}


Table 29. Measured and Calculated Gamma-Ray Doses and Reduction Factors Free-Field/Phantom Facing Reactor

Comparisons with BTI/DREO TLD Measurements

Doses in $\operatorname{mrad}_{\mathrm{Ti}} / \mathrm{kWh}$.

\begin{tabular}{|c|c|c|c|c|c|c|c|c|c|c|}
\hline & \multicolumn{5}{|c|}{ Run Number $129 / 130$} & \multicolumn{2}{|c|}{$50 \mathrm{kWh}$} & \multirow[b]{2}{*}{$\mathrm{C} / \mathrm{M}$} & \multirow[b]{2}{*}{ SAI } & \multirow[b]{2}{*}{$\mathrm{C} / \mathrm{M}$} \\
\hline & Dose & OR & $\mathrm{C} / \mathrm{M}$ & SAI & $\mathrm{C} / \mathrm{M}$ & RF & OR & & & \\
\hline \multicolumn{11}{|c|}{ Free-Field Doses } \\
\hline \multirow[t]{2}{*}{ Out } & 1.24 & 1.34 & 1.08 & 1.33 & 1.07 & & & & & \\
\hline & & & & & & & 3.53 & & 3.69 & \\
\hline Box & & 0.38 & & 0.36 & & & & & & \\
\hline \multicolumn{11}{|c|}{ Doses in Phantom } \\
\hline MH & 1.81 & 1.93 & 1.07 & 1.89 & 1.04 & 0.69 & 0.69 & 1.00 & 0.70 & 1.01 \\
\hline $\mathrm{MG}$ & 1.54 & 1.92 & 1.25 & 1.89 & 1.23 & 0.81 & 0.70 & 0.86 & 0.70 & 0.86 \\
\hline LC & 1.77 & 1.84 & 1.04 & 1.72 & 0.97 & 0.70 & 0.73 & 1.04 & 0.77 & 1.10 \\
\hline LW & 1.42 & 1.51 & 1.06 & 1.51 & 1.06 & 0.87 & 0.88 & 1.01 & 0.88 & 1.01 \\
\hline RW & 1.54 & 1.61 & 1.05 & 1.54 & 1.00 & 0.81 & 0.83 & 1.02 & 0.86 & 1.06 \\
\hline FB & 1.76 & 1.93 & 1.10 & 1.85 & 1.05 & 0.70 & 0.69 & 0.99 & 0.72 & 1.03 \\
\hline $\mathrm{BB}$ & 1.29 & 1.48 & 1.15 & 1.49 & 1.16 & 0.96 & 0.91 & 0.95 & 0.89 & 0.93 \\
\hline AVG & 1.59 & 1.75 & 1.10 & 1.70 & 1.07 & 0.79 & 0.78 & 0.98 & 0.79 & 1.00 \\
\hline STD & 0.20 & 0.20 & 0.07 & 0.18 & 0.09 & 0.10 & 0.10 & 0.06 & 0.09 & 0.08 \\
\hline
\end{tabular}


Table 30. Measured and Calculated Gamma-Ray Doses and Reduction Factors

In-Box/Phantom Facing Reactor

Comparisons with BTI/DREO TLD Measurements

Doses in $\operatorname{mrad}_{\mathrm{Ti}} / \mathrm{kWh}$.

\begin{tabular}{|c|c|c|c|c|c|c|c|c|c|c|}
\hline & \multicolumn{5}{|c|}{ Run Number $127 / 128$} & \multicolumn{2}{|c|}{$50 \mathrm{kWh}$} & \multirow[b]{2}{*}{$\mathrm{C} / \mathrm{M}$} & \multirow[b]{2}{*}{ SAI } & \multirow[b]{2}{*}{$\mathrm{C} / \mathrm{M}$} \\
\hline & Dose & OR & $\mathrm{C} / \mathrm{M}$ & SAI & $\mathrm{C} / \mathrm{M}$ & RF & OR & & & \\
\hline \multicolumn{11}{|c|}{ Free-Field Doses } \\
\hline \multirow[t]{2}{*}{ Out } & 1.37 & 1.33 & 0.97 & 1.27 & 0.93 & & & & & \\
\hline & & & & & & 3.26 & 3.50 & 1.07 & 3.43 & 1.05 \\
\hline Box & 0.42 & 0.38 & 0.90 & 0.37 & 0.88 & & & & & \\
\hline \multicolumn{11}{|c|}{ Doses in Phantom } \\
\hline MH & 0.81 & 0.93 & 1.15 & 0.87 & 1.07 & 1.69 & 1.43 & 0.85 & 1.46 & 0.86 \\
\hline MG & 0.64 & 0.85 & 1.33 & 0.87 & 1.36 & 2.14 & 1.56 & 0.73 & 1.46 & 0.68 \\
\hline LC & 0.71 & 0.66 & 0.93 & 0.68 & 0.96 & 1.93 & 2.01 & 1.04 & 1.87 & 0.97 \\
\hline LW & 0.72 & 0.47 & 0.65 & 0.55 & 0.76 & 1.90 & 2.81 & 1.48 & 2.31 & 1.22 \\
\hline RW & 0.49 & 0.52 & 1.06 & 0.51 & 1.04 & 2.80 & 2.58 & 0.92 & 2.49 & 0.89 \\
\hline FB & 0.64 & 0.69 & 1.08 & 0.73 & 1.14 & 2.14 & 1.94 & 0.91 & 1.74 & 0.81 \\
\hline BB & 0.66 & 0.63 & 0.95 & 0.54 & 0.82 & 2.08 & 2.10 & 1.01 & 2.35 & 1.13 \\
\hline AVG & 0.67 & 0.68 & 1.02 & 0.68 & 1.02 & 2.10 & 2.06 & 0.96 & 1.95 & 0.94 \\
\hline STD & 0.10 & 0.17 & 0.21 & 0.15 & 0.20 & 0.35 & 0.50 & 0.26 & 0.43 & 0.19 \\
\hline
\end{tabular}


Table 31. Measured and Calculated Gamma-Ray Doses and Reduction Factors

Free-Field/Right-Side Facing Reactor

Comparisons with BTI/DREO TLD Measurements

Doses in $\operatorname{mrad}_{\mathrm{Ti}} / \mathrm{kWh}$.

\begin{tabular}{|c|c|c|c|c|c|c|c|c|c|c|}
\hline \multicolumn{11}{|c|}{ Run Number $132 / 133 / 134 \quad 35.2 \mathrm{kWh}$} \\
\hline & Dose & OR & $\mathrm{C} / \mathrm{M}$ & SAI & $\mathrm{C} / \mathrm{M}$ & $\mathrm{RF}$ & OR & $\mathrm{C} / \mathrm{M}$ & SAI & $\mathrm{C} / \mathrm{M}$ \\
\hline \multicolumn{11}{|c|}{ Free-Field Doses } \\
\hline \multirow[t]{2}{*}{ Out } & 1.37 & 1.34 & 0.98 & 1.34 & 0.96 & & & & & \\
\hline & & & & & & & 3.53 & & 4.19 & \\
\hline Box & & 0.38 & & 0.32 & & & & & & \\
\hline \multicolumn{11}{|c|}{ Doses in Phantom } \\
\hline $\mathrm{MH}$ & 1.68 & 1.98 & 1.18 & 1.96 & 1.17 & 0.82 & 0.68 & 0.83 & 0.68 & 0.83 \\
\hline \multirow[t]{2}{*}{ MG } & 1.37 & 1.73 & 1.26 & 1.73 & 1.26 & 1.00 & 0.77 & 0.77 & 0.77 & 0.77 \\
\hline & 1.63 & 1.58 & 0.97 & 1.56 & 0.96 & 0.84 & 0.85 & 1.01 & 0.86 & 1.02 \\
\hline LW & 1.40 & 1.19 & 0.85 & 1.19 & 0.85 & 0.98 & 1.12 & 1.14 & 1.13 & 1.15 \\
\hline $\mathrm{RW}$ & 1.58 & 1.63 & 1.03 & 1.61 & 1.02 & 0.87 & 0.82 & 0.94 & 0.83 & 0.95 \\
\hline FB & 1.55 & 1.68 & 1.08 & 1.68 & 1.08 & 0.88 & 0.80 & 0.91 & 0.80 & 0.91 \\
\hline $\mathrm{BB}$ & 1.68 & 1.72 & 1.02 & 1.70 & 1.01 & 0.82 & 0.78 & 0.95 & 0.79 & 0.96 \\
\hline $\mathrm{AVG}$ & 1.56 & 1.64 & 1.06 & 1.63 & 1.05 & 0.89 & 0.83 & 0.94 & 0.84 & 0.94 \\
\hline STD & 0.13 & 0.24 & 0.14 & 0.23 & 0.14 & 0.07 & 0.14 & 0.12 & 0.14 & 0.12 \\
\hline
\end{tabular}


Table 32. Measured and Calculated Gamma-Ray Doses and Reduction Factors In-Box/Right-Side Facing Reactor

Comparisons with BTI/DREO TLD Measurements Doses in $\operatorname{mrad}_{\mathrm{T}} / \mathrm{kWh}$.

\begin{tabular}{|c|c|c|c|c|c|c|c|c|c|c|}
\hline & \multicolumn{5}{|c|}{ Run Number $135 / 136$} & \multicolumn{5}{|c|}{$23.8 \mathrm{kWh}$} \\
\hline & Dose & OR & $\mathrm{C} / \mathrm{M}$ & SAI & $\mathrm{C} / \mathrm{M}$ & RF & OR & $\mathrm{C} / \mathrm{M}$ & SAI & $\mathrm{C} / \mathrm{M}$ \\
\hline \multicolumn{11}{|c|}{ Free-Field Doses } \\
\hline \multirow[t]{2}{*}{ Out } & 1.32 & 1.32 & 1.00 & 1.33 & 1.04 & & & & & \\
\hline & & & & & & 4.00 & 3.77 & 0.94 & 3.69 & 0.92 \\
\hline Box & 0.33 & 0.35 & 1.06 & 0.36 & 1.06 & & & & & \\
\hline \multicolumn{11}{|c|}{ Doses in Phantom } \\
\hline MH & 0.70 & 0.81 & 1.16 & 0.77 & 1.10 & 1.89 & 1.64 & 0.87 & 1.73 & 0.92 \\
\hline MG & 0.56 & 0.73 & 1.30 & 0.82 & 1.46 & 2.36 & 1.80 & 0.76 & 1.62 & 0.69 \\
\hline LC & 0.59 & 0.55 & 0.93 & 0.57 & 0.97 & 2.24 & 2.39 & 1.07 & 2.33 & 1.04 \\
\hline LW & 0.39 & 0.39 & 1.00 & 0.48 & 1.23 & 3.38 & 3.38 & 1.00 & 2.77 & 0.82 \\
\hline RW & 0.44 & 0.49 & 1.11 & 0.50 & 1.14 & 3.00 & 2.70 & 0.90 & 2.66 & 0.89 \\
\hline $\mathrm{FB}$ & 0.52 & 0.58 & 1.12 & 0.50 & 0.96 & 2.54 & 2.26 & 0.89 & 2.66 & 1.05 \\
\hline $\mathrm{BB}$ & 0.50 & 0.58 & 1.16 & 0.57 & 1.14 & 2.64 & 2.26 & 0.86 & 2.33 & 0.88 \\
\hline AVG & 0.53 & 0.59 & 1.11 & 0.60 & 1.13 & 2.58 & 2.35 & 0.91 & 2.30 & 0.90 \\
\hline STD & 0.10 & 0.14 & 0.12 & 0.14 & 0.17 & 0.49 & 0.58 & 0.10 & 0.46 & 0.12 \\
\hline
\end{tabular}


Table 33. Measured and Calculated Gamma-Ray Doses and Reduction Factors Free-Field/Phantom Facing Reactor

Comparisons with ETCA TLD Measurements

Doses in $\mathrm{mrad}_{\mathrm{Ti}} / \mathrm{kWh}$.

\begin{tabular}{|c|c|c|c|c|c|c|c|c|c|c|}
\hline & \multicolumn{5}{|c|}{ Run Number $129 / 130$} & \multicolumn{5}{|c|}{$50 \mathrm{kWh}$} \\
\hline & Dose & OR & $\mathrm{C} / \mathrm{M}$ & SAI & $\mathrm{C} / \mathrm{M}$ & RF & OR & $\mathrm{C} / \mathrm{M}$ & SAI & $\mathrm{C} / \mathrm{M}$ \\
\hline \multicolumn{11}{|c|}{ Free-Field Doses } \\
\hline \multirow[t]{2}{*}{ Out } & 1.83 & 1.34 & 0.73 & 1.33 & 0.73 & & & & & \\
\hline & & & & & & & 3.53 & & 3.69 & \\
\hline Box & & 0.38 & & 0.36 & & & & & & \\
\hline \multicolumn{11}{|c|}{ Doses in Phantom } \\
\hline $\mathrm{MH}$ & 3.17 & 1.93 & 0.61 & 1.89 & 0.60 & 0.58 & 0.69 & 1.19 & 0.70 & 1.21 \\
\hline MG & 2.41 & 1.92 & 0.80 & 1.89 & 0.78 & 0.76 & 0.70 & 0.92 & 0.70 & 0.92 \\
\hline $\mathrm{LC}$ & 2.23 & 1.84 & 0.83 & 1.72 & 0.77 & 0.82 & 0.73 & 0.89 & 0.77 & 0.94 \\
\hline LW & 2.04 & 1.51 & 0.74 & 1.51 & 0.74 & 0.90 & 0.88 & 0.98 & 0.88 & 0.98 \\
\hline RW & 2.12 & 1.61 & 0.76 & 1.54 & 0.73 & 0.86 & 0.83 & 0.97 & 0.86 & 1.00 \\
\hline FB & 2.29 & 1.93 & 0.84 & 1.85 & 0.81 & 0.80 & 0.69 & 0.86 & 0.72 & 0.90 \\
\hline $\mathrm{BB}$ & 1.85 & 1.48 & 0.80 & 1.49 & 0.81 & 0.99 & 0.91 & 0.92 & 0.89 & 0.90 \\
\hline AVG & 2.30 & 1.75 & 0.77 & 1.70 & 0.75 & 0.82 & 0.78 & 0.96 & 0.79 & 0.98 \\
\hline STD & 0.42 & 0.20 & 0.08 & 0.18 & 0.07 & 0.13 & 0.10 & 0.11 & 0.09 & 0.11 \\
\hline
\end{tabular}


Table 34. Measured and Calculated Neutron Doses and Reduction Factors Free-Field/Phantom Facing Reactor Comparisons with BTI/DREO Bubble Detector Measurements

Doses in $\mathrm{mrad}_{\mathrm{Ti}} \mathrm{kWh}$.

\begin{tabular}{|c|c|c|c|c|c|c|c|c|c|c|}
\hline \multicolumn{11}{|c|}{ Run Number 120} \\
\hline & Dose & OR & $\mathrm{C} / \mathrm{M}$ & SAI & $\mathrm{C} / \mathrm{M}$ & $\mathrm{RF}$ & OR & $\mathrm{C} / \mathrm{M}$ & SAI & $\mathrm{C} / \mathrm{M}$ \\
\hline \multicolumn{11}{|c|}{ Free-Field Doses } \\
\hline \multirow[t]{2}{*}{ Out } & 4.09 & 4.90 & 1.20 & 5.01 & 1.22 & & & & & \\
\hline & & & & & & & 1.62 & & 1.67 & \\
\hline Box & & 3.03 & & 2.99 & & & & & & \\
\hline \multicolumn{11}{|c|}{ Doses in Phantom } \\
\hline $\mathrm{MH}$ & 0.90 & 1.20 & 1.33 & 1.10 & 1.22 & 4.54 & 4.08 & 0.90 & 4.55 & 1.00 \\
\hline$M G$ & 0.69 & 0.74 & 1.07 & 0.83 & 1.20 & 5.93 & 6.62 & 1.12 & 6.04 & 1.02 \\
\hline LC & 3.67 & 4.52 & 1.23 & 4.58 & 1.25 & 1.11 & 1.08 & $0.9 ?$ & 1.09 & 0.98 \\
\hline LW & 3.24 & 4.35 & 1.34 & 4.09 & 1.26 & 1.26 & 1.13 & 0.90 & 1.22 & 0.97 \\
\hline RW & 4.17 & 4.40 & 1.06 & 4.12 & 0.99 & 0.98 & 1.11 & 1.13 & 1.22 & 1.24 \\
\hline $\mathrm{FB}$ & 3.38 & 4.47 & 1.32 & 4.49 & 1.33 & 1.21 & 1.10 & 0.91 & 1.11 & 0.92 \\
\hline $\mathrm{BB}$ & 1.57 & 1.62 & 1.03 & 1.57 & 1.00 & 2.61 & 3.02 & 1.16 & 3.19 & 1.22 \\
\hline AVG & 2.52 & 3.04 & 1.19 & 2.97 & 1.18 & 1.62 & 1.61 & 1.01 & 1.43 & 1.05 \\
\hline STD & 1.42 & 1.76 & 0.12 & 1.71 & 0.13 & 2.86 & 2.79 & 0.12 & 2.78 & 0.13 \\
\hline
\end{tabular}


Table 35. Measured and Calculated Neutron Doses and Reduction Factors In-Box/Phantom Facing Reactor

Comparisons with BTI/DREO Bubble Detector Measurements

Doses in $\operatorname{mrad}_{\mathrm{Ti}} / \mathrm{kWh}$.

\begin{tabular}{|c|c|c|c|c|c|c|c|c|c|c|}
\hline \multicolumn{11}{|c|}{ Run Number $122 / 123$} \\
\hline & Dose & OR & $\mathrm{C} / \mathrm{M}$ & SAI & $\mathrm{C} / \mathrm{M}$ & $\mathrm{RF}$ & OR & $\mathrm{C} / \mathrm{M}$ & SAI & $\mathrm{C} / \mathrm{M}$ \\
\hline \multicolumn{11}{|c|}{ Free-Field Doses } \\
\hline \multirow[t]{2}{*}{ Out } & 4.27 & 4.90 & 1.15 & 5.19 & 1.22 & & & & & \\
\hline & & & & & & 1.74 & 1.74 & 1.00 & 1.81 & 1.04 \\
\hline Box & 2.46 & 2.82 & 1.15 & 2.86 & 1.16 & & & & & \\
\hline \multicolumn{11}{|c|}{ Doses in Phantom } \\
\hline $\mathrm{MH}$ & 0.32 & 0.41 & 1.28 & 0.45 & 1.41 & 13.34 & 11.95 & 0.90 & 11.53 & 0.86 \\
\hline MG & 0.25 & 0.20 & 0.80 & 0.22 & 0.88 & 17.08 & 24.50 & 1.43 & 23.59 & 1.38 \\
\hline LC & 2.33 & 2.35 & 1.01 & 2.50 & 1.07 & 1.83 & 2.09 & 1.14 & 2.08 & 1.14 \\
\hline LW & 2.05 & 2.45 & 1.20 & 2.44 & 1.19 & 2.08 & 2.00 & 0.96 & 2.13 & 1.02 \\
\hline RW & 2.35 & 2.36 & 1.00 & 2.49 & 1.06 & $1.8:$ & 2.08 & 1.14 & 2.08 & 1.14 \\
\hline FB & 1.91 & 2.27 & 1.19 & 2.32 & 1.21 & 2.24 & 2.16 & 0.96 & 2.24 & 1.00 \\
\hline $\mathrm{BB}$ & 1.24 & 1.47 & 1.19 & 1.63 & 1.31 & 3.44 & 3.33 & 0.97 & 3.18 & 0.92 \\
\hline$A V G$ & 1.49 & 1.63 & 1.10 & 1.72 & 1.16 & 2.86 & 2.98 & 1.07 & 3.02 & 1.07 \\
\hline STD & 0.90 & 1.03 & 0.17 & 1.00 & 0.18 & 4.72 & 5.04 & 0.19 & 5.22 & 0.17 \\
\hline
\end{tabular}


Table 36. Measured and Calculated Neutron Doses and Reduction Factors Free-Field/Right Side Facing Reactor

Comparisons with BTI/DREO Bubble Detector Measurements

Doses in $\mathrm{mrad}_{\mathrm{T}} / \mathrm{kWh}$.

\begin{tabular}{|c|c|c|c|c|c|c|c|c|c|c|}
\hline \multicolumn{11}{|c|}{ Run Number 119} \\
\hline & Dose & OR & $\mathrm{C} / \mathrm{M}$ & SAI & $\mathrm{C} / \mathrm{M}$ & $\mathrm{RF}$ & OR & $\mathrm{C} / \mathrm{M}$ & SAI & $\mathrm{C} / \mathrm{M}$ \\
\hline \multicolumn{11}{|c|}{ Free-Field Doses } \\
\hline \multirow[t]{2}{*}{ Out } & 4.16 & 4.90 & 1.18 & 5.02 & 1.21 & & & & & \\
\hline & & & & & & & 1.62 & & 1.68 & \\
\hline Box & & 3.03 & & 3.00 & & & & & & \\
\hline \multicolumn{11}{|c|}{ Doses in Phantom } \\
\hline $\mathrm{MH}$ & 0.81 & 1.38 & 1.70 & 1.27 & 1.57 & 5.14 & 3.55 & 0.69 & 3.95 & 0.77 \\
\hline MG & 0.50 & 0.44 & 0.88 & 0.45 & 0.90 & 8.32 & 11.14 & 1.34 & 11.16 & 1.34 \\
\hline $\mathrm{LC}$ & 2.45 & 3.17 & 1.29 & 3.02 & 1.23 & 1.70 & 1.55 & 0.91 & 1.66 & 0.98 \\
\hline LW & 1.84 & 2.34 & 1.27 & 2.27 & 1.23 & 2.26 & 2.09 & 0.92 & 2.21 & 0.98 \\
\hline RW & 3.59 & 4.47 & 1.25 & 4.63 & 1.29 & 1.16 & 1.10 & 0.95 & 1.08 & 0.93 \\
\hline $\mathrm{FB}$ & 2.45 & 3.39 & 1.38 & 3.37 & 1.38 & 1.70 & 1.45 & 0.85 & 1.49 & 0.88 \\
\hline $\mathrm{BB}$ & 2.10 & 3.29 & 1.57 & 2.79 & 1.33 & 1.98 & 1.49 & 0.75 & 1.80 & 0.91 \\
\hline AVG & 1.96 & 2.64 & 1.33 & 2.54 & 1.28 & 3.18 & 3.20 & 0.92 & 3.34 & 0.97 \\
\hline STD & 1.05 & 1.36 & 0.26 & 1.38 & 0.20 & 2.61 & 3.59 & 0.21 & 3.57 & 0.18 \\
\hline
\end{tabular}


Table 37. Measured and Calculated Neutron Doses and Reduction Factors In-Box/Right Side Facing Reactor

Comparisons with BTI/DREO Bubble Detector Measurements

Doses in $\mathrm{mrad}_{\mathrm{Ti}} / \mathrm{kWh}$.

\begin{tabular}{|c|c|c|c|c|c|c|c|c|c|c|}
\hline \multicolumn{11}{|c|}{ Run Number $124 / 125$} \\
\hline & Dose & OR & $\mathrm{C} / \mathrm{M}$ & SAI & $\mathrm{C} / \mathrm{M}$ & RF & OR & $\mathrm{C} / \mathrm{M}$ & SAI & $\mathrm{C} / \mathrm{M}$ \\
\hline \multicolumn{11}{|c|}{ Free-Field Doses } \\
\hline \multirow[t]{2}{*}{ Out } & 3.57 & 4.90 & 1.37 & 5.29 & 1.48 & & & & & \\
\hline & & & & & & 1.42 & 1.74 & 1.23 & 1.81 & 1.27 \\
\hline Box & 2.52 & 2.82 & 1.12 & 2.91 & 1.15 & & & & & \\
\hline \multicolumn{11}{|c|}{ Doses in Phantom } \\
\hline $\mathrm{MH}$ & 0.43 & 0.44 & 1.02 & 0.53 & 1.23 & 8.30 & 11.14 & 1.34 & 9.98 & 1.20 \\
\hline MG & 0.18 & 0.16 & 0.89 & 0.18 & 1.00 & 19.83 & 30.63 & 1.54 & 29.39 & 1.48 \\
\hline LC & 1.75 & 1.91 & 1.09 & 2.17 & 1.24 & 2.04 & 2.57 & 1.26 & 2.44 & 1.20 \\
\hline $\mathbf{L W}$ & 1.81 & 1.97 & 1.09 & 1.91 & 1.06 & 1.97 & 2.48 & 1.26 & 2.77 & 1.41 \\
\hline RW & 2.55 & 2.49 & 0.98 & 2.76 & 1.08 & 1.40 & 1.97 & 1.41 & 1.92 & 1.37 \\
\hline FB & 1.73 & 1.90 & 1.10 & 2.08 & 1.20 & 2.06 & 2.58 & 1.25 & 2.54 & 1.23 \\
\hline $\mathrm{BB}$ & 1.68 & 1.90 & 1.13 & 2.17 & 1.29 & 2.13 & 2.58 & 1.21 & 2.44 & 1.15 \\
\hline$A V G$ & 1.45 & 1.54 & 1.04 & 1.69 & 1.16 & 5.39 & 7.71 & 1.32 & 7.35 & 1.29 \\
\hline STD & 0.84 & 0.88 & 0.08 & 0.95 & 0.11 & 6.80 & 10.62 & 0.12 & 10.12 & 0.13 \\
\hline
\end{tabular}




\section{REFERENCES}

1. J. O. Johnson, "A User's Manual for MASH 1.0 - A Monte Carlo Adjoint Shielding Code System," Oak Ridge National Laboratory, ORNL/TM-11778, (March 1991)

2. W. A. Rhoades and M. B. Emmett et al., Vehicle Code System (VCS) User's Manual," Oak Ridge National Laboratory, ORNL/TM-4648, (August 1974)

3. W. A. Rhoades et. al., "Development of a Code System for Determining Radiation Protection of Armored Vehicles (The VCS Code)," Oak Ridge National Laboratory, ORNL/TM-4664, (October 1974)

4. J. O. Johnson, J. D. Drischler, and J. M. Barnes, "Analysis of the Fall-1989 Two-Meter Box Test Bed Experiments Performed at the Army Pulse Radiation Facility (APRF)," Oak Ridge National Laboratory, ORNL/TM-11777, (May 1991)

5. Dean C. Kaul and Stephen D. Egbert, "Radiation Environments Program (REP) The Verification \& Validation of MASH 1991, 1990, 1989," presented at the REP Program Meeting, WWD, Munster, Germany, 28-29 July 1992 (Unpublished)

6. R. T. Santoro et. el., "DNA Radiation Environments Program Fall 1989 2-Meter Box Experiments and Analysis," Oak Ridge National Laboratory, ORNL/TM-11840, (May 1991)

7. K. Tremblay, H. Ing, and R. A. Noulty, "Anthropomorphic Phantom Radiation Dosimetry Measurements," Bubble Technology Industries, Inc., BTI-90/6-6, (1992)

8. J. O. Johnson, J. D. Drischler, and J. M. Barnes, "Analysis of the Spring 1990 TwoMeter Box Test Bed Experiments Performed at the Army Pulse Radiation Facility (APRF)," Oak Ridge National Laboratory, ORNL/TM-11917, (August 1992)

9. Mark A. Oliver, "APRF Gamma Dose Measurements," Letter Report (Unpublished)

10. A. H. Kazi, "The Phantom In-A-Box Experiment of MAY 1990," Slide presentation made to the 1991 Radiation Environments Prograrn Review, (Unpublished)

11. K. G. Kerris, "HDL Gamma Dose Measurements Using $\mathrm{CaF}_{2}: \mathrm{Mn}$ TLD's," Diamond Laboratories, October 1990, (Unpublished)

12. Guy Nurdin, "Neutron and Gamma Fields in the Vicinity of the APRF Reactor with an Anthropomorphic Source and the Real Profile of the Ground,"Establissement Technique Central del'Armement, Centre'd Etudes du Bouchet, 94114 Arcueil, France, (Unpublished) 
13. D. T. Ingersoll, R. W. Roussin, C. Y. Fu, and J. E. White, "DABL69: A Broad Group Neutron/Photon Cross-Section Library for Defense Nuclear Applications," ORNL/TM10568 Oak Ridge National Laboratory, (June 1989) 
APPENDIX A 


\section{SPRING 1990 2-METER BOX EXPERIMENTS}

List of Participants by Organization

\section{EXPERIMENTALISTS}

Army Pulse Radiation Facility Aberdeen Proving Ground, Maryland, USA 21005-5059

C. H. Heimbach, M. A. Oliver, A. H. Kazi

Bubble Technology Industries

Ottawa, Canada K0J1J0

H. Ing, K. Trembly

Defence Research Establishment Ottawa

Ottawa, Canada K1A024

T. E. Cousins, B. E. Hoffarth

Establissement Technique Central del'Armement

Centre'd Etudes du Bouchet

94114 Arcueil, France

J. Dhermain, G. Nurdin, J. Laugier

$$
\begin{gathered}
\text { Harry Diamond Laboratory } \\
2300 \text { Powder Mill Road } \\
\text { Adelphi, Maryland, USA } \\
\text { K. Kerris }
\end{gathered}
$$

\section{ANALYSTS}

Oak Ridge National Laboratory

P.O. Box 2008

Oak Ridge, Tennessee, USA 37831

J. M. Barnes, J. D. Drischler, J. O. Johnson

Science Applications International Corporation

San Diego, California USA 92121

S. D. Egbert, D. C. Kaul 


\section{INTERNAL DISTRIBUTION}

1. B. R. Appleton

2. J. M. Barnes

3. T. J. Burns

4. J. D. Drischler

5. C. M. Haaland

6. D. T. Ingersoll

7-11. J. O. Johnson

12. J. V. Pace

13. W. A. Rhoades

14. R. W. Roussin

15-23. R. T. Santoro
24. R. C. Ward 25-26. EPMD Reports Office 27-28. Laboratory Records Department

29. Laboratory Records ORNL-RC

30. Document Reference Section

31. Central Research Library

32. ORNI. Patent Section

EXTERNAL DISTRIBUTION

33. Director, Defense Nuclear Agency

ATTN: RARP (Dr. D. L. Auton)

6801 Telegraph Road

Alexandria, VA 22310-3398

34. Dr. Roger W. Brockett

Wang Professor of Electrical Engineering and Computer Science

Division of Applied Science

Harvard University

Cambridge, Massachusetts 02138

35. Dr. N. Ricky Byrn

Nicholes Research Corp.

4040 So. Memorial Parkway

Huntsville, AL 35802

36. Director, Harry Diamond Laboratory

ATTN: SLCHD-NW-P (Mr. John Corrigan)

2800 Powder Mill Road

Adelphi, MD 20783-1197 
37. Electronics Division, NES

ATTN: Dr. Tom Cousins

Defence Research Establishment Ottawa

Ottawa, Ontario, Canada, K1A OZ4

38. Commander, U.S. Army Nuclear \& Chemical Agency

ATTN: MONA-ZB (Dr. David Bash)

7500 Backlick Rd., Bldg. 2073

Springfield, VA 22150-3198

39. Establissment Technique Central de l' Armement

ATTN: Dr. Joel Dhermain

Centre d'Etudes du Boucher

16 bis Avenue Prieur de la Cote d'or

94114 Arcueil-Cedex, France

40. Dr. John J. Dorning

Department of Nuclear Engineering \& Engineering Physics

Thorton Hall, McCormick Road

University of Virginia

Chrlottesville, Va 22901

41. Science Applications International Corporation

ATTN: Dr. Stephen Egbert

10260 Campus Point Drive

San Diego, CA 92121

42. Commander, U.S. Army Combat Systems Test Activity

ATTN: STECS-NE (Mr. John Gerdes)

Aberdeen Proving Ground, MD 21005-5059

43. Ministry of Defence, Atomic Weapons Establishment

ATTN: Dr. Kevin G. Harrison

Building A72, Aldermaston,

Reading, Berkshire, United Kingdom, RG7 4PR

44. Commander, U.S. Army Combat Systems Test Activity

ATTN: STECS-NE (Dr. C. Heimbach)

Aberdeen Proving Ground, MD 21005-5059

45. Director, Bubble Technology Industries, Inc.

ATTN: Dr. Harry Ing

Highway 17

Chalk River, Ontario, Canada, KOJ 1 JO

46. Science Applications International Corporation

ATTN: Mr. Dean C. Kaul

10260 Campus Point Drive

San Diego, CA 92121 
47. Commander, U.S. Army Combat Systems Test Activity ATTN: STECS-NE (Dr. A. Halim Kazi)

Aberdeen Proving Ground, MD 21005-5059

48. Director, Armed Forces Radiobiology Research Institute ATTN: MRAD (CDR Kearsly)

Bethesda, MD 20814-5145

49. Director, Defense Nuclear Agency

ATTN: RARP (MAJ Robert Kehlet)

6801 Telegraph Road

Alexandria, VA 22310-3398

50. Director, Harry Diamond Laboratory

ATTN: SLCHD-NW-P (Mr. Klaus Kerris)

2800 Powder Mill Road

Adelphi, MD 20783-1197

51. US Army Center for EQ/RSTA

ATTN: AMSEL-RSK (Dr. Stanley Kronenberg)

Fort Monmouth, NY 07703

52. Establissment Technique Central de l' Armement

ATTN: Dr. Jacques Laugier

Centre d'Etudes du Boucher

16 bis Avenue Prieur de la Cote d'or

94114 Arcueil-Cedex, France

53. Dr. James E. Leiss

Route 2, Box 142C

Broadway, VA 22815

54. Dr. Neville Moray

Department of Mechanical and Industrial Engineering

University of Illinois

1206 West Green Street

Urbana, Il 61801

55. Director, Defense Nuclear Agency

ATTN: RARP (Ms. Joan Ma Pierre)

6801 Telegraph Road

Alexandria, VA 22310-3398

56. Naval Surface Warfare Center

ATTN: CODE R41 (Mr. Gordon Reil)

New Hampshire Road

White Oak, MD 20903-5000 
57. Commander, U.S. Army Foreign Science \& Technology Center ATTN: UVA (Dr. Roger Rydin)

2207 th Street NE

Charlottesville, VA 22901-5396

58. HEAD, Nuclear Radiation Effects

ATTN: Dr. Ludwig Schaenzler

Wehrwissenschaftliche Dienststelle

Postfach 1320

3042 Munster

Federal Republic of Germany

59. David L. Tilson

U.S. Army SDC

ATTN: CSSD-SA-EV

P.O. BOx 1500

Huntsville, AL 35807

60. Commander, U.S. Army Foreign Science \& Technology Center ATTN: AIFRTA (Mr. Charles Ward)

2207 th Street NE

Charlottesville, VA 22901-5396

61. Dr. Mary F. Wheeler

Department of Mathematical Sciences

Rice University

P. D. Box 1892

Houston, Tx 77204-3476

62. Commander, U.S. Army Tank Automotive Command ATTN: AMSTA-RSK (Mr. Greg Wolfe)

Bldg. 200

Warren, MI 48317-5000

63. Director, Defense Nuclear Agency

ATTN: RARP (Dr. Robert Young)

6801 Telegraph Road

Alexandria, VA 22310-3398

64. Office of the Assistant Manager for Energy

Research and Development

Department of Energy, Oak Ridge Operations

P.O. Box 2001

Oak Ridge, TN 37831

65-74. Office of Scientific and Technical Information

P.O. Box 62

Oak Ridge, TN 37830 
75-77. S. Y. Whitaker 1830 Delphine Drive Decatur, GA 30032 

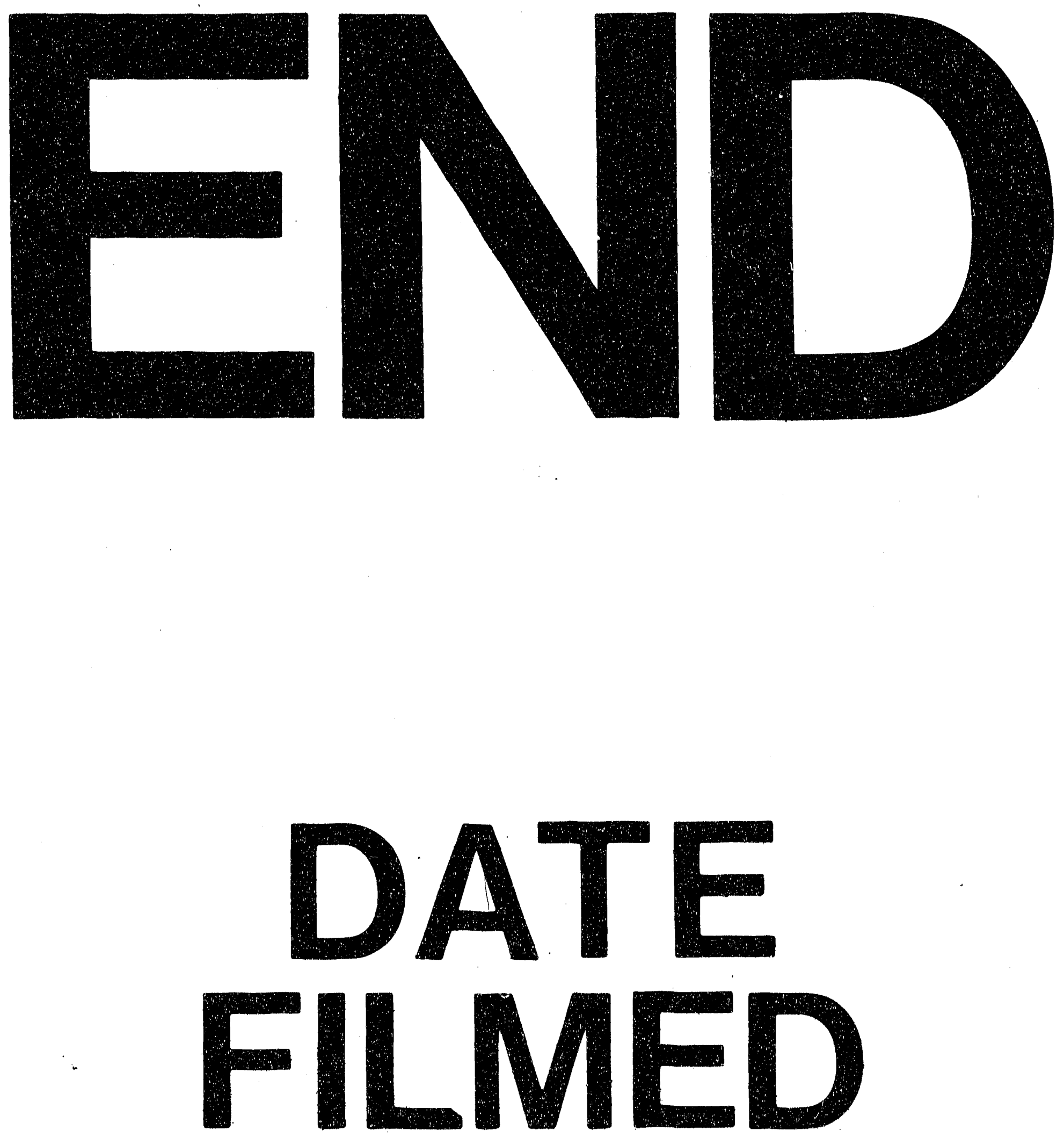

㐁

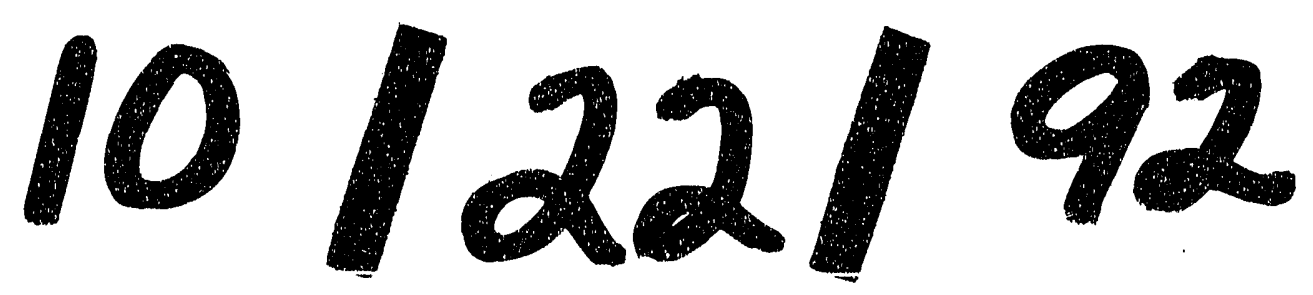


